\title{
Therapeutic effects of adipose-derived mesenchymal stem cells against brain death-induced remote organ damage and post- heart transplant acute rejection
}

\author{
Hon-Kan Yip ${ }^{1,2,3,4,5, *}$, Mel S. Lee ${ }^{6, *}$, Cheuk-Kwan Sun ${ }^{7}$, Kuan-Hung Chen ${ }^{8}$, Han-Tan \\ Chai ${ }^{1}$, Pei-Hsun Sung ${ }^{1}$, Kun-Chen Lin ${ }^{8}$, Sheung-Fat Ko ${ }^{9}$, Chun-Man Yuen ${ }^{10}$, Chu- \\ Feng Liu ${ }^{11}$, Pei-Lin Shao ${ }^{5}$ and Fan-Yen Lee ${ }^{12}$ \\ ${ }^{1}$ Division of Cardiology, Department of Internal Medicine, Kaohsiung Chang Gung Memorial Hospital and Chang Gung \\ University College of Medicine, Kaohsiung, Taiwan \\ ${ }^{2}$ Institute for Translational Research in Biomedicine, Kaohsiung Chang Gung Memorial Hospital, Kaohsiung, Taiwan \\ ${ }^{3}$ Center for Shockwave Medicine and Tissue Engineering, Kaohsiung Chang Gung Memorial Hospital and Chang Gung \\ University College of Medicine, Kaohsiung, Taiwan \\ ${ }^{4}$ Department of Medical Research, China Medical University Hospital, China Medical University, Taichung, Taiwan \\ ${ }^{5}$ Department of Nursing, Asia University, Taichung, Taiwan \\ ${ }^{6}$ Department of Orthopedics, Kaohsiung Chang Gung Memorial Hospital and Chang Gung University College of Medicine, \\ Kaohsiung, Taiwan \\ ${ }^{7}$ Department of Emergency Medicine, E-Da Hospital, I-Shou University School of Medicine for International Students, \\ Kaohsiung, Taiwan \\ ${ }^{8}$ Department of Anesthesiology, Kaohsiung Chang Gung Memorial Hospital and Chang Gung University College of Medicine, \\ Kaohsiung, Taiwan \\ ${ }^{9}$ Department of Radiology, Kaohsiung Chang Gung Memorial Hospital and Chang Gung University College of Medicine, \\ Kaohsiung, Taiwan \\ ${ }^{10}$ Division of Neurosurgery, Department of Surgery, Kaohsiung Chang Gung Memorial Hospital and Chang Gung University \\ College of Medicine, Kaohsiung, Taiwan \\ ${ }^{11}$ Department of Emergency Medicine, Kaohsiung Chang Gung Memorial Hospital and Chang Gung University College of \\ Medicine, Kaohsiung, Taiwan \\ ${ }^{12}$ Division of Thoracic and Cardiovascular Surgery, Department of Surgery, Kaohsiung Chang Gung Memorial Hospital and \\ Chang Gung University College of Medicine, Kaohsiung, Taiwan \\ *These authors have contribute equally to this work \\ Correspondence to: Fan-Yen Lee, email: fanyenlee2015@gmail.com
}

Keywords: brain death, heart transplantation, inflammation, immunogenicity, remote organ damage

Received: June 05, $2017 \quad$ Accepted: August 04, $2017 \quad$ Published: September 30, 2017

Copyright: Yip et al. This is an open-access article distributed under the terms of the Creative Commons Attribution License 3.0 (CC BY 3.0), which permits unrestricted use, distribution, and reproduction in any medium, provided the original author and source are credited.

\section{ABSTRACT}

We tested the hypothesis that allogenic adipose-derived mesenchymal stem cells (ADMSCs) alleviated brain death (BD)-induced remote organ damage and events of post heart-transplant acute rejection. To determine the impact of BD on remote organ damage, adult-male $\mathrm{F344}$ rats $(n=24)$ were categorized sham-control $(\mathrm{SC})$, $B D$ and $B^{M S C}$ (allogenic ADMSC/1.2 ${ }^{\text {M }} 10^{6}$ cells/derived from F344 by intravenous transfusion $3 \mathrm{~h}$ after BD procedure). To determine the protective effect of allogenic ADMSCs, animals ( $n=8 /$ each group in $F 344 /$ Lewis) were categorized into groups BD-T(F344 heart transplanted into Lewis by $6 \mathrm{~h}$ after BD), BD-T ${ }^{\mathrm{MSC}(\mathrm{D} 1 / 3)}$ (BD induction for $6 \mathrm{~h}$ then heart transplantation, and allogenic ADMSCs transfusion at days 1 and 5 after heart transplantation), BD-T ${ }^{\mathrm{MSC}(3 \mathrm{~h})}\left(\mathrm{BD}+\mathrm{ADMSC} / 1.2 \times 10^{6}\right.$ cells at $3 \mathrm{~h}$ and heart 
transplantation at $6 \mathrm{~h}$ after BD) and BD-TMSC(3h, D1/3) [BD + ADMSC/1.2 $\times 10^{6}$ cells at $3 \mathrm{~h}$ and heart transplantation at $6 \mathrm{~h}$ after BD, then ADMSC therapy by days 1/3]. At day 5 post procedure, liver, kidney and heart specimens showed higher molecular-cellular levels of inflammation, immune reaction, apoptosis and fibrosis in BD than in SC that were reversed in BD $^{\text {MSC }}$ (all $P$ < $\mathbf{0 . 0 0 0 1}$ ). These molecular-cellular expressions and circulating/splenic levels of innate/adoptive immune cells were higher in BD-T, lowest in $B D-T^{M S C(3 h, ~ D 1 / 3) ~ a n d ~ h i g h e r ~ B D-~}{ }^{M S C(3 h)}$ in than $B D-T^{M S C(D 1 / 3)}$, whereas heart function showed an opposite pattern among the four groups (all $P<0.001$ ). In conclusion, ADMSCs suppressed BD-caused remote organ damage and heart-transplant rejection.

\section{INTRODUCTION}

Advanced congestive heart failure (CHF) in its terminal stage is the most important contributor to cardiac death among all cardiovascular diseases [1-3]. Despite state-of-the-art pharmacomodulation [4-13] and refinement of therapeutic strategies [14-17], the incidence of death in patients with decompensated CHF remains extremely high with an estimated incidence of more than $50 \%$ per year and has remained unchanged over the last few decades [1-3]. Therefore, heart transplantation is the last life-saving resort for patients with advanced decompensated CHF [18-21]. However, two critical problems: (1) an extremely limited number of donors (i.e., shortage of donor hearts), and (2) rejection after heart transplantations remain unresolved. With regard to the first issue, to date there is no effective strategy. Intriguingly, for the second issue, although pre-transplant major histocompatibility complex (MHC) matching between donor and recipient has been routine and advanced immunosuppressive regimens have been extensively utilized after heart transplantation, rejection is still a bottleneck for transplant success. This suggests that unidentified confounders may exist.

The donors for heart transplantation are always brain-death (BD) victims. Interestingly, our previous study has shown that, as compared with normal control and risk-control subjects, patients with acute ischemic stroke [4] had significantly higher circulating level of $\mathrm{N}$-terminal pro-brain natriuretic peptide (NT-proBNP) [22]. Additionally, as compared to less severe IS patients, patients with more severe IS also had significantly higher incidence of advanced CHF, myocardial infarction, and in-hospital death as well as lower left ventricular ejection fraction (LVEF) [22, 23]. Other recent experimental and clinical observation studies [24-27] have not only consistently revealed findings similar to ours $[22,23]$, but also exhibited up to more than $25 \%$ patients with lower LVEF even at the early stage of BD [28]. These findings [22-28] raised the hypothesis that organ function may be impaired in BD patients.

Our clinical observational study has previously shown that circulating inflammatory mediators were significantly increased in patients after acute IS [23, 29 33] and furthermore higher in those of severe IS patients [23, 29-33]. Furthermore, the link between severity of brain damage and inflammatory and immune reactions has been identified in our and other previous studies [23, 29, 32-36]. Importantly, these biomarkers have been shown to be predictive of the prognostic outcome of patients after IS in our previous studies [23, 29-33].

Experimental studies have demonstrated that vigorous inflammatory reaction and hyper-reactive immune response commonly occur in circulation [37] and in major organs such as liver, heart and kidney after BD in animals [34-36]. These major organs are consistently injured from the inflammatory and immune reactions after BD [23, 29-38]. These findings led to the hypothesis that BD commonly causes molecular-cellular perturbations and malfunction of remote organs mainly through enhancing inflammatory and immune responses, resulting in increased risk of organ transplantation failure [39].

A body of studies has shown that mesenchymal stem cells (MSCs) have the capacity to be anti-inflammatory [40-43] and immunomodulatory [44-48]. Consistently, our studies have shown that adipose-derived mesenchymal stem cells (ADMSC) possess anti-inflammatory, anti-apoptotic, anti-fibrosis, anti-oxidative stress and immunomodulation activities in various settings of ischemia-related organ damage, including acute IS [4244, 49]. However, no data has been presented to address the therapeutic impact of MSCs against BD-induced damage in remote organs and acute rejection after heart transplantation. Thus, using an experimental model of BD and heart transplantation, we tested the hypothesis that ADMSC therapy might effectively protect remote organs from BD-induced injury and acute rejection after heart transplantation in rodents.

\section{RESULTS}

\section{Pathophysiological findings, inflammatory biomarkers and apoptotic cells in circulation, and circulating/splenic immune cells at $6 \mathrm{~h}$ after the $\mathrm{BD}$ procedure}

Figure 1 illustrates the pathophysiological findings (i.e., heart rate and blood pressure) in BD F344 rats. The results showed that during the $\mathrm{BD}$ period (maintained for $6 \mathrm{~h}$ ), the mean heart rate was about 255.98 beats $/ \mathrm{min}$ and the mean blood pressure was $42.6 \mathrm{mmHg}$, suggesting 
the experimental model of BD was successfully created. Additionally, the gross anatomical picture shows that the pressure area of the brain has the appearance of local hemorrhagic, supporting an appropriate application of pressure-induced BD in F433 rats.
To elucidate the circulating level of inflammatory reaction after $\mathrm{BD}$, the enzyme-linked immunosorbent assay (ELISA) and flow cytometric analysis were utilized in the present study. The results of ELISA showed that at 6 $\mathrm{h}$ after BD procedure, circulating levels of tumor necrosis
(A)

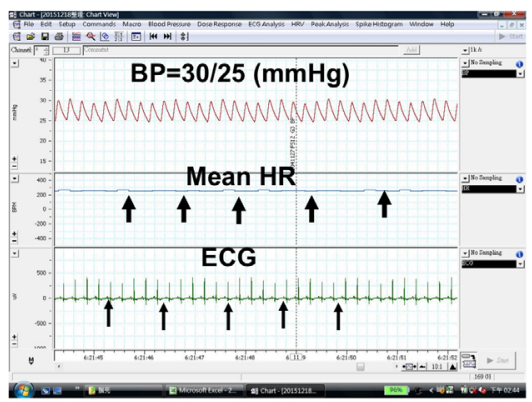

(E)

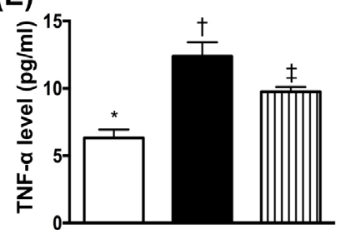

(I)

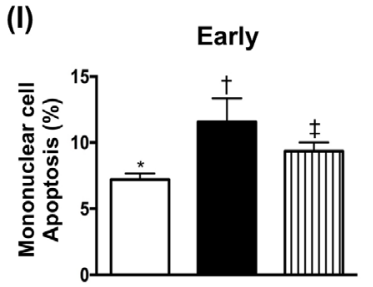

(M)

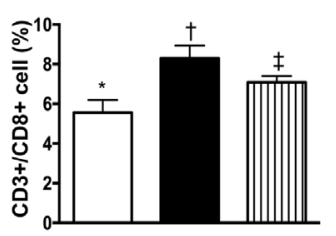

(B)

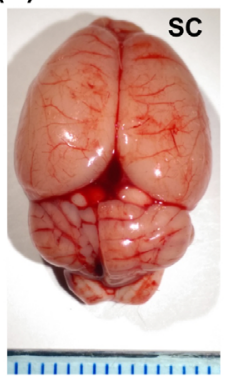

(G)

(F)

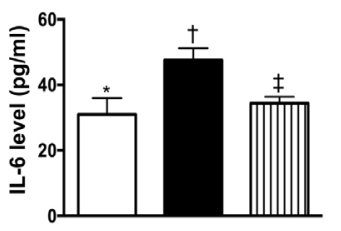

(J)

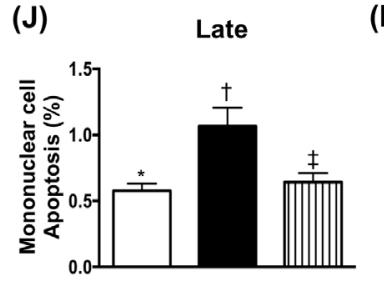

(N)
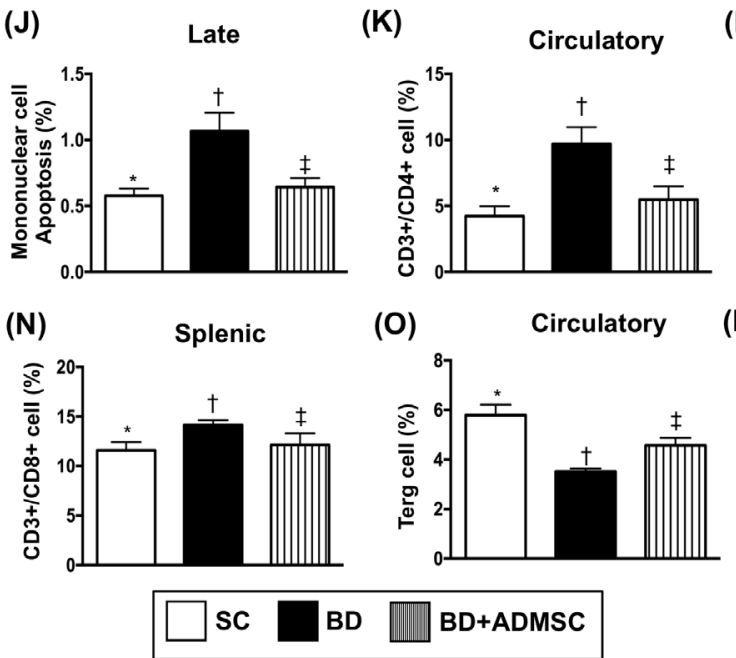

(D)
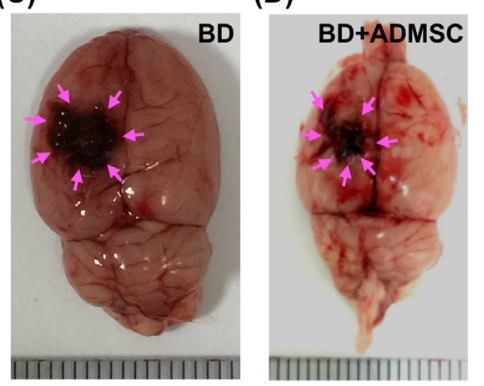

(H)

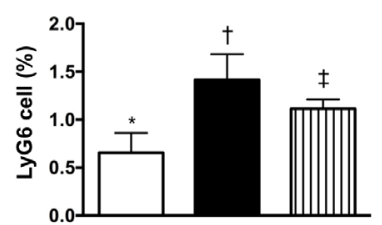

(L)

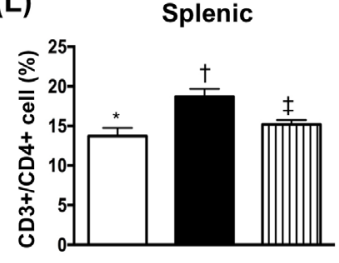

(P)

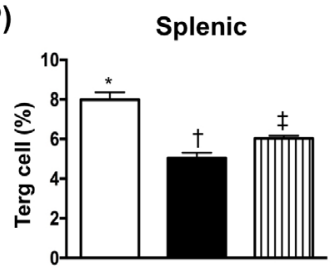

Figure 1: Pathophysiological findings, ELISA assessment and flow cytometric analyses of inflammatory/apoptotic biomarkers and immune cells in circulation at $6 \mathrm{~h}$ after the BD procedure. (A) Illustrating the hemodynamic status (i.e., maximal mean blood pressure in all animals was recorded as $42.66 \pm 3.8 \mathrm{mmHg} / \mathrm{n}=8$ ), mean heart rate $/ 255.98 \pm 11.2$ beat per minute (black arrows), and electrocardiogram recording (black arrows) in brain death (BD) animals. (B to D) Illustrating grossly anatomical picture of brain in sham control (B), BD animal (C) and BD animal + ADMSC treated animals (D). The pink arrows indicated the brain damage (i.e., by pressure compression) in BD animals. (E) ELISA analysis of circulating level of tumor necrosis factor (TNF)- $\alpha$ by $6 \mathrm{~h}$ after $\mathrm{BD}$ procedure, ${ }^{*}$ vs. other groups with different symbols $(\dagger, \$), p<0.001$. (F) ELISA analysis of circulating level of interleukin- 6 by $6 \mathrm{~h}$ after BD procedure, * vs. other groups with different symbols $(\dagger,+), \mathrm{p}<0.01$. (G) Flow cytometric analysis of MPO level, * vs. other groups with different symbols $(\dagger, \ddagger), p<0.0001$. (H) Flow cytometric analysis of LyG6 cell levels, * vs. other groups with different symbols $(\dagger, \$)$, $\mathrm{p}<0.01$. (I) Early apoptosis, * vs. other groups with different symbols ( $\dagger, \$), \mathrm{p}<0.001$. (J) Late apoptosis, * vs. other groups with different symbols $(\dagger, \ddagger), p<0.001$. (K) Circulating levels of CD3+/CD4+ cells (helper T cells), $*$ vs. other groups with different symbols $(\dagger, \$)$, $\mathrm{p}<0.001$. (L) Splenic levels of CD3+/CD4+ cells, * vs. other groups with different symbols ( $\dagger,+$ ), $\mathrm{p}<0.001$. (M) Circulating levels of CD3+/ CD8+ cells (cytotoxic T cells), * vs. other groups with different symbols $(\dagger, \$), \mathrm{p}<0.001$. (N) Splenic levels of CD3+/CD8+ cells, * vs. other groups with different symbols $(\dagger, \$), \mathrm{p}<0.01$. (O) Circulating levels of CD4+CD25+Foxp3+ cells (Treg cells), ${ }^{*}$ vs. other bars with different symbols $(\dagger, \$), \mathrm{p}<0.01$. (P) Splenic levels of Treg cells, ${ }^{*}$ vs. other groups with different symbols $(\dagger, \$), \mathrm{p}<0.001$. All statistical analyses were performed by one-way ANOVA, followed by Bonferroni multiple comparison post hoc test $(\mathrm{n}=8)$. Symbols $(*, \dagger, \ddagger)$ indicate significance (at 0.05 level). $\mathrm{BD}=$ brain death; group $\mathrm{A} 1=$ sham control; group $\mathrm{A} 2=$ brain death; group $\mathrm{A} 3=$ brain death + adipose-derived mesenchymal stem cell (ADMSC). 
factor (TNF)- $\alpha$, interleukin (IL)-6, and myeloperoxidase (MPO), three indicators of inflammatory markers implicating innate immune response, were higher in the $\mathrm{BD}$ group than in the sham control (SC) and the $\mathrm{BD}+$ ADMSC group $\left(\mathrm{BD}^{\mathrm{MSC}}\right)$, and significantly higher in $\mathrm{BD}^{\mathrm{MSC}}$ group than in SC.

The flow cytometric analysis showed that the circulating level of LyG6, an indicator of inflammatory cells showed an identical pattern to the circulating level of inflammatory biomarkers among the three groups. Consistently, the circulating level of early and late apoptotic cells exhibited an identical pattern of LyG6 among the three groups.

To assess the circulating and splenic levels of immune cells, flow cytometric analysis was utilized in the present study. The results demonstrated that circulating and splenic levels CD3+/CD4+ and CD3+/CD8+ cells, two indices of immune cells, were significantly higher in $\mathrm{BD}$ than in $\mathrm{SC}$ and $\mathrm{BD}^{\mathrm{MSC}}$, and significantly higher in $\mathrm{BD}^{\mathrm{MSC}}$ than in $\mathrm{SC}$, whereas the circulating and spleen level of Treg+ cells (i.e., helps end an immune response), showed an opposite pattern of CD3+/CD4+ cells among the three groups.

\section{Protein expression of inflammatory and anti- inflammatory biomarkers in heart, liver and kidney by $6 \mathrm{~h}$ after the BD procedure}

Additionally, Western blot analysis was also performed for determining the proinflammatory biomarkers in heart, liver and kidney. The results exhibited that the protein expressions of TNF- $\alpha$, NF$\kappa \mathrm{B}$, IL-6 and matrix metalloproteinase (MMP)-9, four indicators of inflammation in the liver, kidney and heart were significantly higher in $\mathrm{BD}$ than in $\mathrm{SC}$ and $\mathrm{BD}^{\mathrm{MSC}}$, and significantly higher in $\mathrm{BD}^{\mathrm{MSC}}$ than in $\mathrm{SC}$ (Figure 2). On the other hand, the protein expression of IL-10 and IL-34, two indicators of anti-inflammation, showed an opposite pattern of inflammation among the three groups (Figure 2).

\section{Protein and cellular expression of inflammatory biomarkers in the brain at $6 \mathrm{~h}$ after BD procedure}

To measure the proinflammatory biomarkers in the brain tissue, Western blot analysis was used. The results showed that the protein expression of TNF- $\alpha$ and nuclear factor $(\mathrm{NF})-\kappa \mathrm{B}$, two indicators of inflammation and high mobility group protein-1 (HMG-1), an indicator of cytokine mediator of inflammation, were higher in BD than in $\mathrm{SC}$ and $\mathrm{BD}^{\mathrm{MSC}}$, and significantly higher in $\mathrm{BD}^{\mathrm{MSC}}$ than in SC (Figure 3). Additionally, cellular expressions of CD69+ and F4/80+ cells (i.e., a macrophage surface marker), two indices of inflammation, exhibited an identical pattern of protein expression of inflammation among the three groups (Figure 3).

\section{Cellular expression of inflammatory biomarkers in the heart, liver and kidney at $6 \mathrm{~h}$ after the BD procedure}

Microscopy was utilized for identification of inflammatory cell expressions in heart, liver and kidney. The cellular expressions of CD14+ and CD68+ cells, two indices of inflammation in the liver (Figure 4), kidney (Figure 5) and heart (Figure 6), were significantly higher in $\mathrm{BD}$ than in $\mathrm{SC}$ and $\mathrm{BD}^{\mathrm{MSC}}$, and significantly higher in $\mathrm{BD}^{\mathrm{MSC}}$ than in $\mathrm{SC}$.

\section{Anatomical-pathological findings and echocardiographic findings prior to and at day 5 after BD}

Grossly anatomical structure of each heart was assessed in details. As expected, pathological findings showed that as compared to normal heart, the transplanted heart was severely destroyed at day 5 after the transplantation procedure, suggesting an occurrence of acute transplanted heart rejection (Figure 7). However, the transplanted heart was notably protected by ADMSC therapy at a time period of $3 \mathrm{~h}$ after the BD procedure (i.e., allogenic ADMSC administration to donor prior to transplantation) and furthermore protected by the ADMSC treatment just after the transplant procedure (i.e., allogenic ADMSC administration to the recipients, Lewis rats) as well as AMDS treatment at the two time points (i.e., prior to and after F344 heart transplantation to Lewis), implying that allogenic ADMSC therapy protected the transplanted heart from graft versus host disease (Figure 7).

For assessment of the functional changes of the heart, transthoracic echocardiographic examination was performed for each animal. As expected, prior to BD, the transthoracic echocardiographic examination showed that the LVEF did not differ among the four groups: BD-T (F344 heart transplanted into Lewis by $6 \mathrm{~h}$ after BD), BD$\mathrm{T}^{\mathrm{MSC}(\mathrm{D} 1 / 3)}$ (BD induction for $6 \mathrm{~h}$ then heart transplantation, and allogenic ADMSCs transfusion at days 1 and 3 after heart transplantation), $\mathrm{BD}-\mathrm{T}^{\mathrm{MSC}(3 \mathrm{~h})}(\mathrm{BD}+\mathrm{ADMSC} / 1.2 \times$ $10^{6}$ cells at $3 \mathrm{~h}$ and heart transplantation at $6 \mathrm{~h}$ after $\left.\mathrm{BD}\right)$ and $\mathrm{BD}-\mathrm{T}^{\mathrm{MSC}(3 \mathrm{~h}, \mathrm{D} 1 / 3)}\left[\mathrm{BD}+\mathrm{ADMSC} / 1.2 \times 10^{6}\right.$ cells at $3 \mathrm{~h}$ and heart transplantation at $6 \mathrm{~h}$ after $\mathrm{BD}$, then ADMSC therapy by days $1 / 3$ ]. However, by day 5 prior to the animals being euthanized, this parameter was highest in $\mathrm{BD}-\mathrm{T}^{\mathrm{MSC}(3 \mathrm{~h}, \mathrm{D} 1 / 3)}$, lowest in $\mathrm{BD}-\mathrm{T}$, and significantly higher in $\mathrm{BD}-\mathrm{T}^{\mathrm{MSC}(\mathrm{D} 1 / 3)}$ than in $\mathrm{BD}-\mathrm{T}^{\mathrm{MSC}(3 \mathrm{~h})}$, suggesting that allogenic ADMSC treatment protected the heart function against acute immune rejection-induced damage (Figure 7). 
Flow cytometric analysis of inflammatory cells in circulation and in the spleen and protein expression of apoptotic, fibrotic and anti-fibrotic biomarkers in transplanted LV myocardium by day 5 after heart transplantation

The circulating level of $\mathrm{Ly} 6 \mathrm{G}+$ cells, an indicator of inflammation, was highest in BD-T and lowest in BD$\mathrm{T}^{\mathrm{MSC}(3 \mathrm{~h}, \mathrm{Dl} / 3)}$, and significantly higher in $\mathrm{BD}-\mathrm{T}^{\mathrm{MSC}(3 \mathrm{~h})}$ than in $\mathrm{BD}-\mathrm{T}^{\mathrm{MSC}(\mathrm{D} 1 / 3)}$. Additionally, circulating and splenic levels of $\mathrm{CD} 3+/ \mathrm{CD} 4+$ and $\mathrm{CD} 3+/ \mathrm{CD} 8+$ cells (i.e., helps end an immune response) expressed an identical pattern, whereas Treg+ cells (i.e., an indicator of T-helper cells) exhibited an opposite pattern of Ly6G+ cells among the four groups (Figure 8).

The flow cytometric analysis showed that the early apoptotic cells were highest in BD-T and lowest in BD-

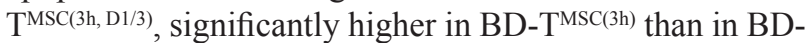
$\mathrm{T}^{\mathrm{MSC}(\mathrm{D} 1 / 3)}$. Additionally, the late apoptotic cells displayed a similar pattern of early apoptosis except for no difference between BD-T ${ }^{\mathrm{MSC}(\mathrm{D} 1 / 3)}$ and BD-T ${ }^{\mathrm{MSC}(3 \mathrm{~h})}$ (Figure 8).

The protein expressions of cleaved caspase 3 and cleaved poly(ADP-ribose) polymerase (PARP), two indicators of apoptosis, and protein expressions of Smad3 and transforming growth factor (TGF)- $\beta$, two indicators of fibrosis, displayed an identical pattern, whereas the protein
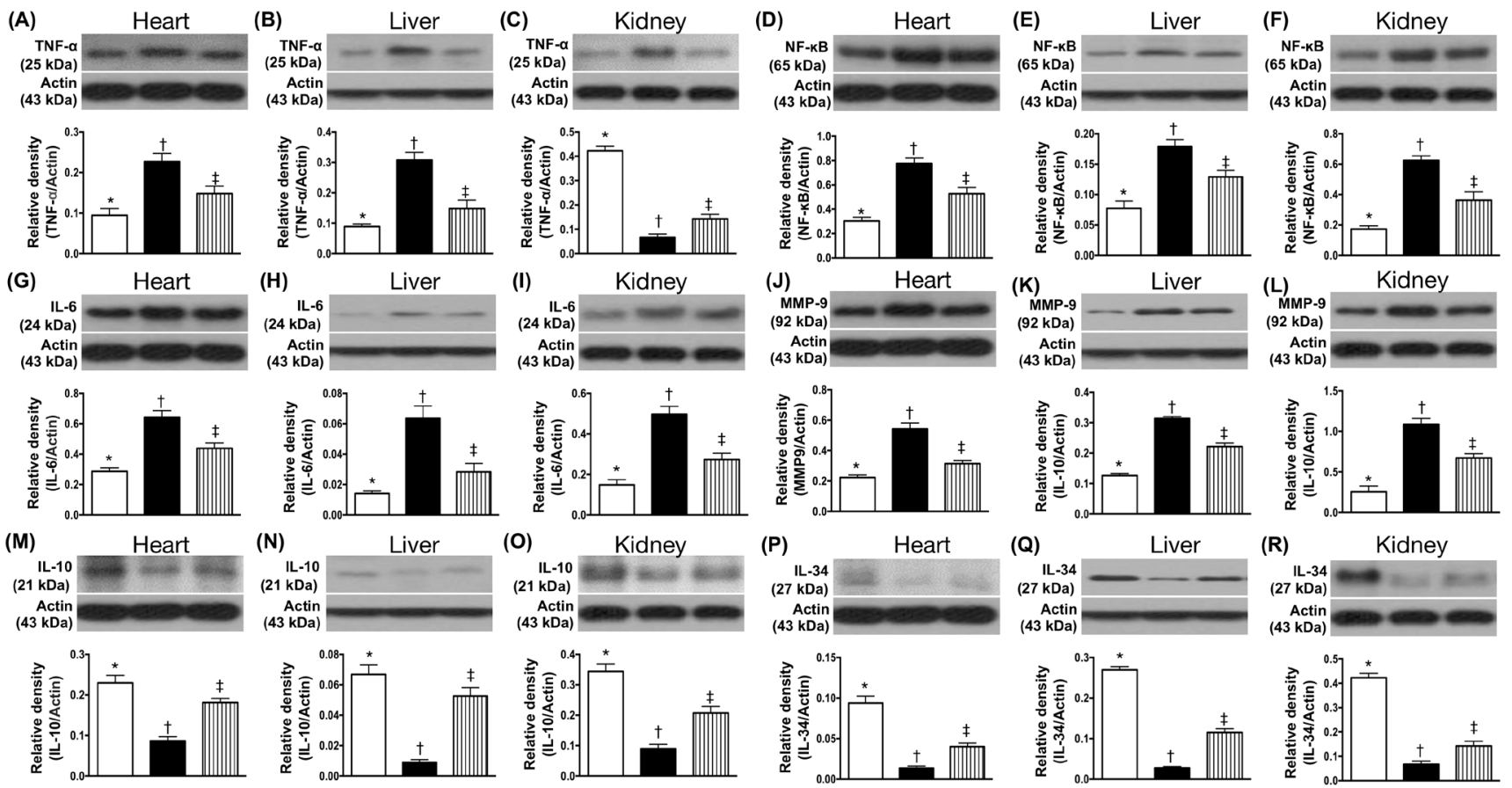

SC $\square$ BD

Figure 2: Protein expressions of inflammatory and anti-inflammatory biomarkers of heart, liver and kidney by 6 h after BD procedure. (A) Protein expression of tumor necrosis factor (TNF)- $\alpha$ in heart, * vs. other groups with different symbols ( $\dagger$, $\$), \mathrm{p}<0.001$. (B) Protein expression of TNF- $\alpha$ in liver, ${ }^{*}$ vs. other groups with different symbols $(\dagger, \$)$, $p<0.001$. (C) Protein expression of TNF- $\alpha$ in kidney, ${ }^{*}$ vs. other groups with different symbols $(\dagger,+), p<0.0001$. (D) Protein expression of nuclear factor (NF)- $\kappa B$ in heart, $*$ vs. other groups with different symbols $(\dagger, \dagger), \mathrm{p}<0.001$. (E) Protein expression of NF- $\kappa B$ in liver, * vs. other groups with different symbols $(\dagger$, $\ddagger$ ), $\mathrm{p}<0.001$. (F) Protein expression of NF- $\kappa \mathrm{B}$ in kidney, ${ }^{*}$ vs. other groups with different symbols $(\dagger, \ddagger), \mathrm{p}<0.001$. (G) Protein expression of interleukin [6]-6 in heart, * vs. other groups with different symbols $(\dagger, \$), \mathrm{p}<0.001$. (H) Protein expression of IL-6 in liver, * vs. other groups with different symbols $(\dagger, \ddagger), \mathrm{p}<0.001$. (I) Protein expression of IL-6 in kidney, $*$ vs. other groups with different symbols $(\dagger, \ddagger$ ), $\mathrm{p}<0.001$. (J) Protein expression of matrix metalloproteinase (MMP)-9 in heart, ${ }^{*}$ vs. other groups with different symbols $(\dagger,+), p<0.001$. (K) Protein expression of MMP-9 in liver, * vs. other groups with different symbols $(\dagger, \$), \mathrm{p}<0.001$. (L) Protein expression of MMP-9 in kidney, ${ }^{*}$ vs. other groups with different symbols $(\dagger, \$), p<0.001$. (M) Protein expression of IL-10 in heart, $*$ vs. other groups with different symbols $(\dagger, \ddagger), \mathrm{p}<0.001$. (N) Protein expression of IL-10 in liver, ${ }^{*}$ vs. other groups with different symbols $(\dagger, \ddagger), \mathrm{p}<0.0001$. (O) Protein expression of IL-10 in kidney, * vs. other groups with different symbols $(\dagger, \$), \mathrm{p}<0.001$. (P) Protein expression of IL-34 in heart, * vs. other groups with different symbols $(\dagger,+), \mathrm{p}<0.001$. (Q) Protein expression of IL-34 in liver, ${ }^{*}$ vs. other groups with different symbols0 $(\dagger,+)$, $\mathrm{p}<0.0001$. (R) Protein expression of IL-34 in kidney, ${ }^{*}$ vs. other groups with different symbols $(\dagger, \dagger), \mathrm{p}<0.0001$. All statistical analyses were performed by one-way ANOVA, followed by Bonferroni multiple comparison post hoc test $(n=8)$. Symbols $(*, \dagger, \ddagger)$ indicate significance (at 0.05 level). $\mathrm{BD}=$ brain death; group $\mathrm{A} 1$ = sham control; group $\mathrm{A} 2$ = brain death; group $\mathrm{A} 3$ = brain death + adipose-derived mesenchymal stem cell (ADMSC). 
(A)
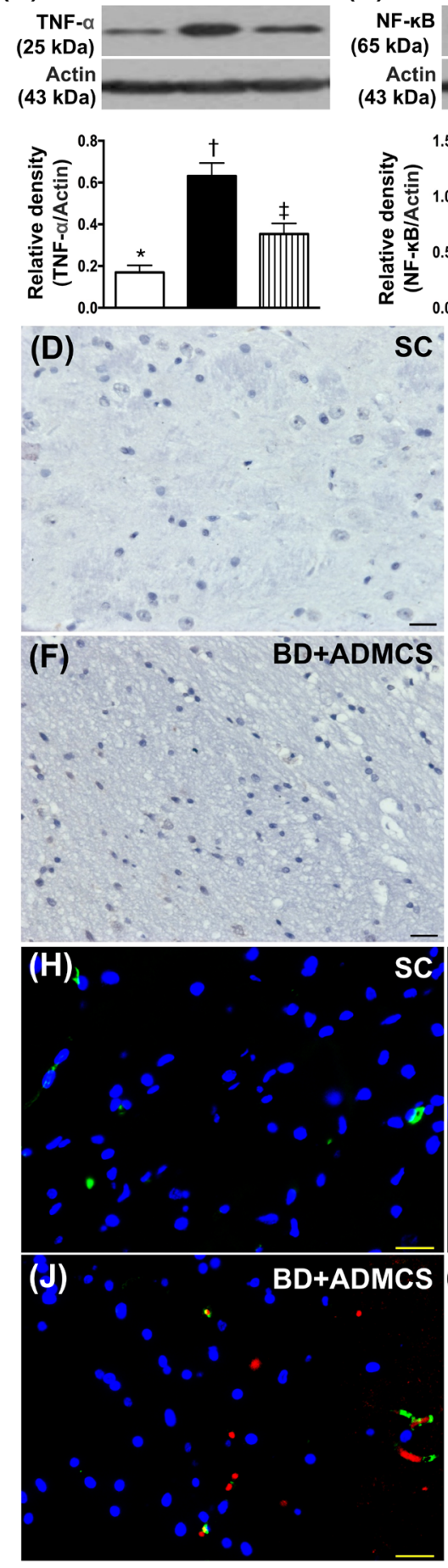

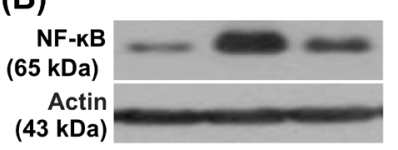

(C)
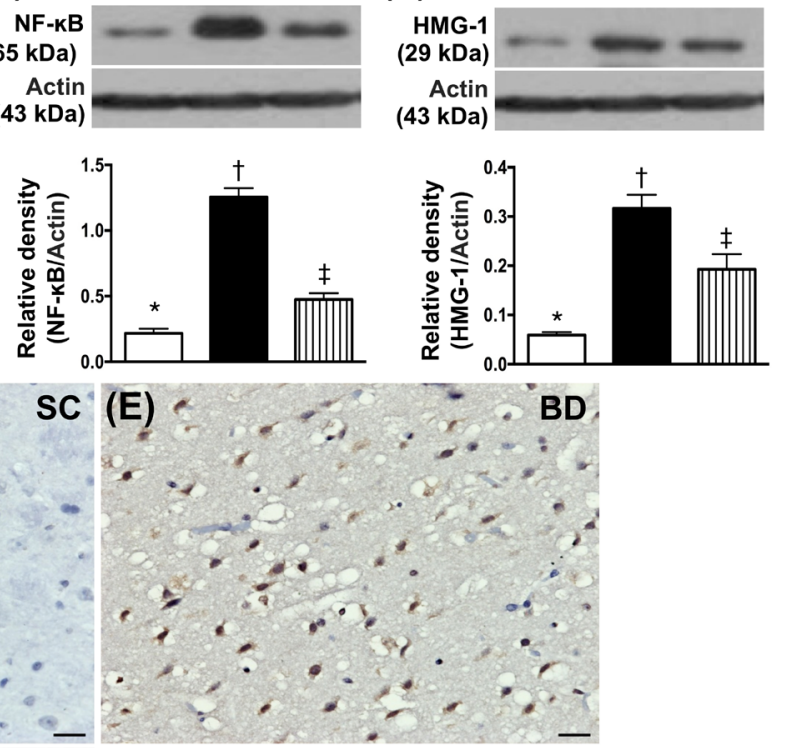

(G)
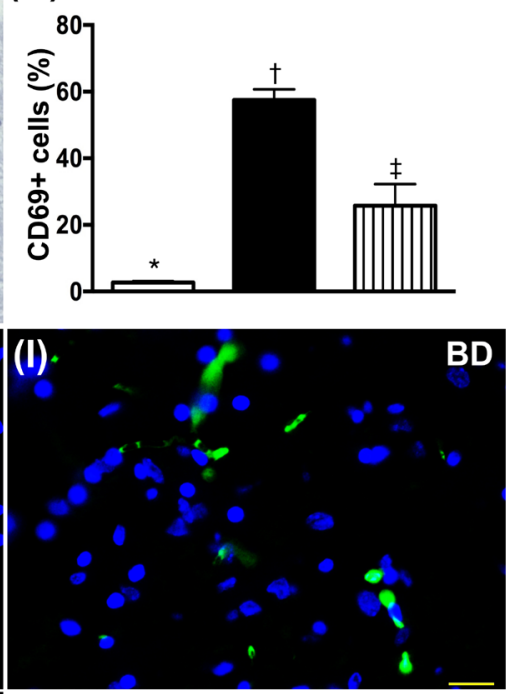

(K)

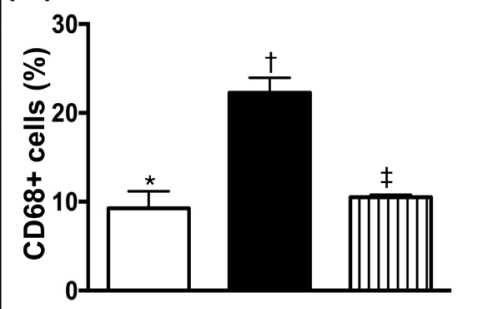

Figure 3: The protein and cellular expressions of inflammatory biomarkers in brain at $6 \mathrm{~h}$ after BD procedure. (A) Protein expression of tumor necrosis factor (TNF)- $\alpha$ * vs. other bars with different symbols, $p<0.0001$. (B) Protein expression of nuclear factor (NF)-kB, * vs. other groups with different symbols $(\dagger, \$), \mathrm{p}<0.0001$. (C) Protein expression of high-mobility group protein-1 (HMG1 ), * vs. other groups with different symbols ( $\dagger, \ddagger$ ), $\mathrm{p}<0.0001$. (D to $\mathbf{F})$ Illustrating microscopic finding (200x) of immunohistochemical staining for identification of CD69+ cells (gray color). The scale bars in right lower corner represent $50 \mu \mathrm{m}$. (G) Analytical result of number of positively-stained CD69 cells, * vs. other groups with different symbols $(\dagger, \ddagger), \mathrm{p}<0.001$. (H to J) Illustrating microscopic finding (400x) of immunofluorescent staining for identification of F4/80+ cells (green color). Red color in [1] indicated Dil-dye positively-stained ADMSCs in brain tissue. The scale bars in right lower corner represent $20 \mu \mathrm{m}$. (K) Analytical result of number of positively-stained F4/80 cells, * vs. other groups with different symbols $(\dagger, \ddagger), \mathrm{p}<0.001$. All statistical analyses were performed by one-way ANOVA, followed by Bonferroni multiple comparison post hoc test $(\mathrm{n}=8)$. Symbols $(*, \uparrow, \ddagger)$ indicate significance (at 0.05 level). $\mathrm{BD}=$ brain death; group $\mathrm{A} 1=$ sham control; group A2 = brain death; group A3 = brain death + adipose-derived mesenchymal stem cell (ADMSC). 

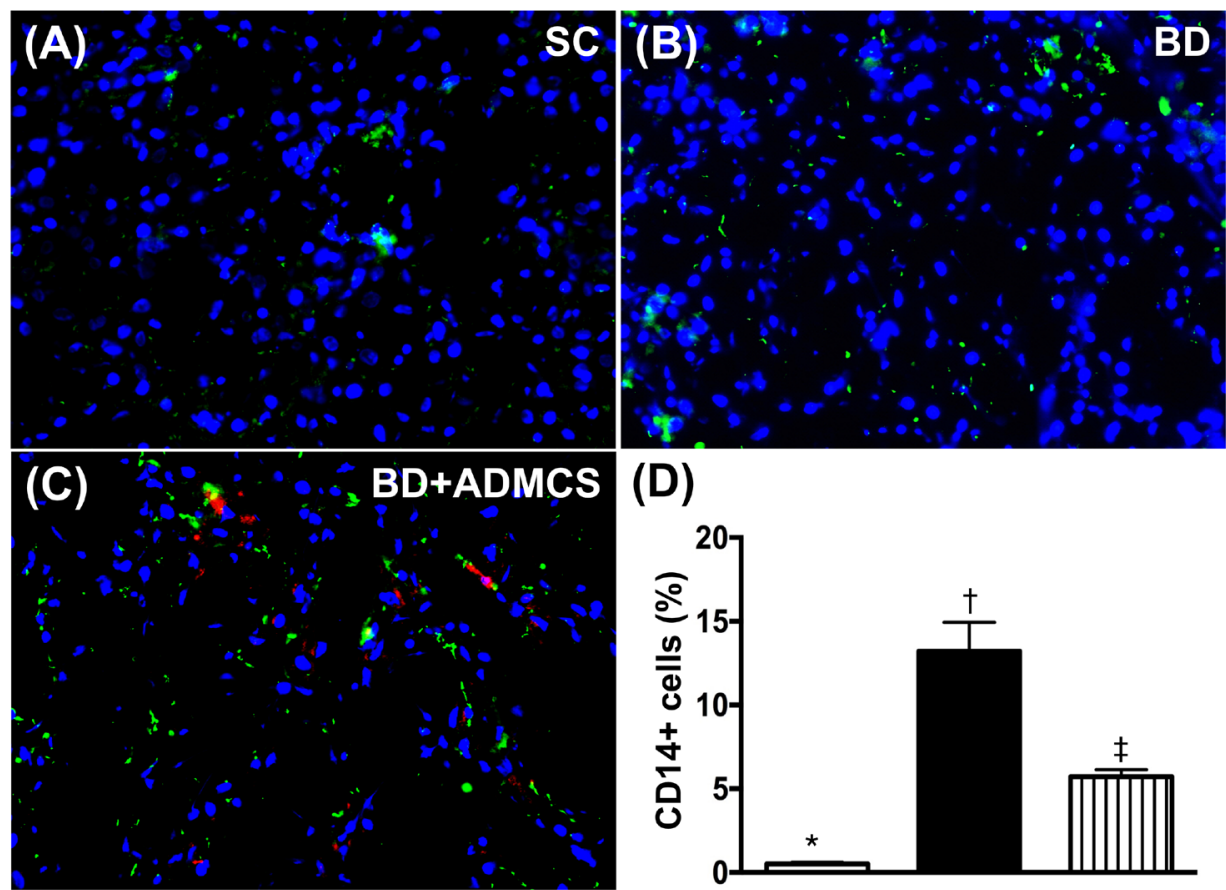

(D)
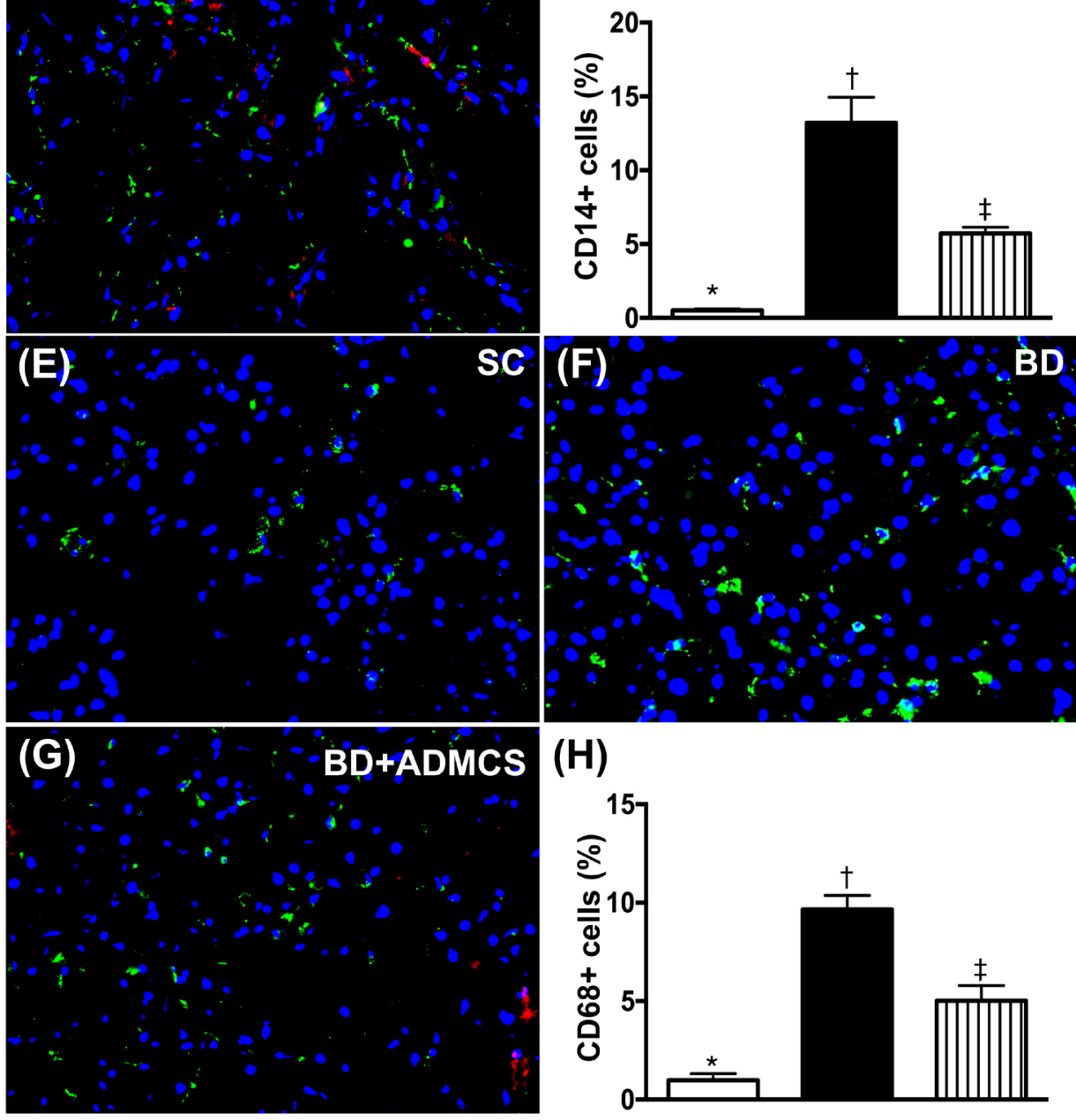

\section{$(\mathrm{H})$}

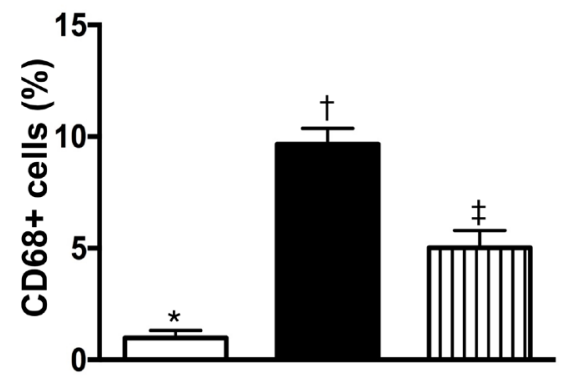

SC

BD

BD+ADMSC

Figure 4: Cellular expressions of inflammatory biomarkers in heart at $6 \mathrm{~h}$ after BD procedure. (A-C) Illustrating immunofluorescent (IF) microscopic finding (400x) for identifying CD14+ cells (green color). Red color in [4] indicated some Dil-dye positively-stained ADMSCs in heart tissue. (D) Analytical result of number of positively-stained CD cells, ${ }^{*}$ vs. other groups with different symbols ( $\dagger,+$ ), $p<0.0001$. (E to G) IF microscopic finding (400x) for identifying CD68+ cells (green color). Red color in (G) indicated some Dil-dye positively-stained ADMSCs in heart tissue. (H) Analytical result of number of positively-stained CD68+ cells, * vs. other groups with different symbols $(\dagger, \dagger), \mathrm{p}<0.0001$. The scale bars in right lower corner represent $20 \mu \mathrm{m}$. All statistical analyses were performed by one-way ANOVA, followed by Bonferroni multiple comparison post hoc test $(n=8)$. Symbols $(*, \dagger, \ddagger)$ indicate significance (at 0.05 level). $\mathrm{BD}=$ brain death; group A1 = sham control; group A2 = brain death; group A3 = brain death + adipose-derived mesenchymal stem cell (ADMSC). 

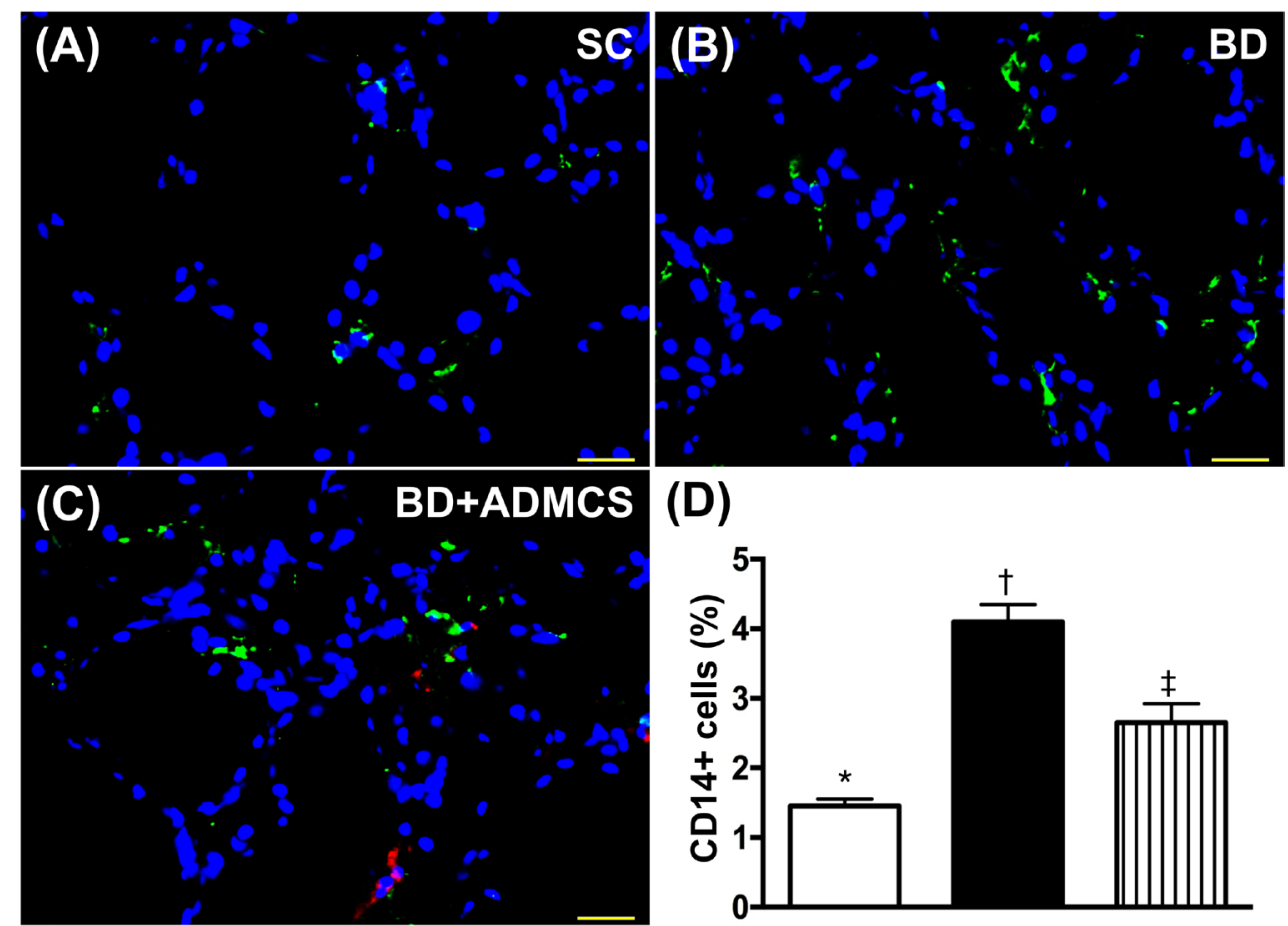

(D)
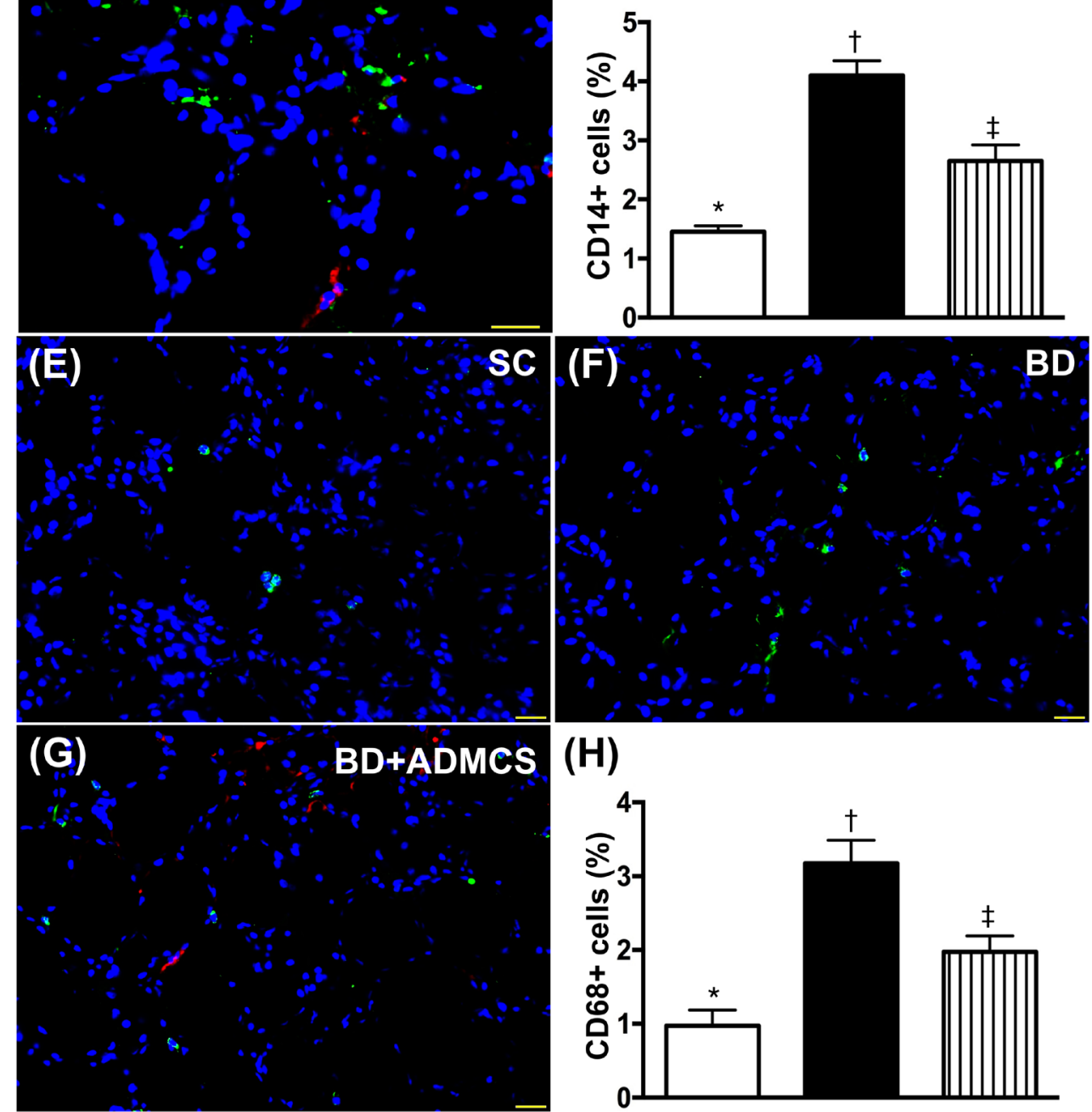

(H)
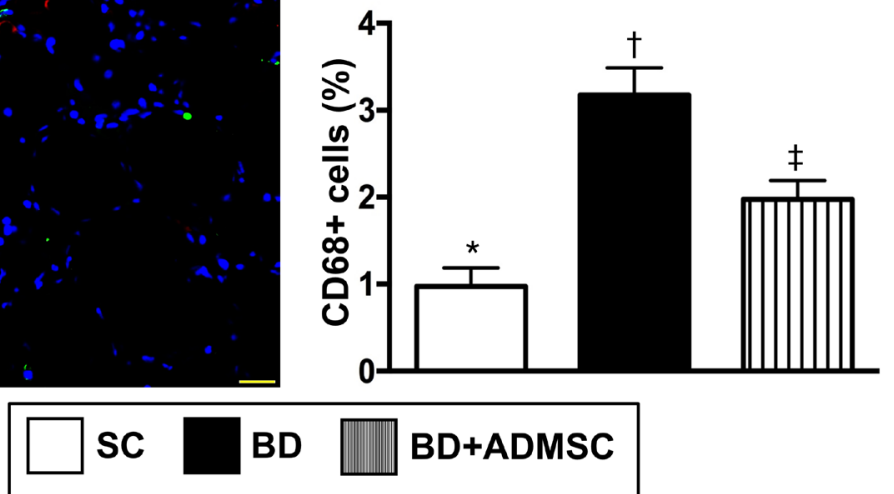

Figure 5: Cellular expressions of inflammatory biomarkers in liver at $6 \mathbf{~ h}$ after BD procedure. (A to C) Illustrating immunofluorescent (IF) microscopic finding (400x) for identifying CD14+ cells (green color). Red color in [4] indicated some Dil-dye positively-stained ADMSCs in heart tissue. (D) Analytical result of number of positively-stained CD14 cells, * vs. other groups with different symbols $(\dagger, \$), \mathrm{p}<0.0001$. (E to $\mathbf{G})$ IF microscopic finding (400x) for identifying CD68+ cells (green color). Red color in [4] indicated some Dil-dye positively-stained ADMSCs in heart tissue. (H) Analytical result of number of positively-stained CD68+ cells, * vs. other groups with different symbols $(\dagger, \dagger), \mathrm{p}<0.0001$. The scale bars in right lower corner represent $20 \mu \mathrm{m}$. All statistical analyses were performed by one-way ANOVA, followed by Bonferroni multiple comparison post hoc test $(\mathrm{n}=8)$. Symbols $(*$, $\dagger$, + ) indicate significance (at 0.05 level). $\mathrm{BD}=$ brain death; group $\mathrm{A} 1=$ sham control; group $\mathrm{A} 2$ = brain death; group $\mathrm{A} 3$ = brain death + adipose-derived mesenchymal stem cell (ADMSC). 


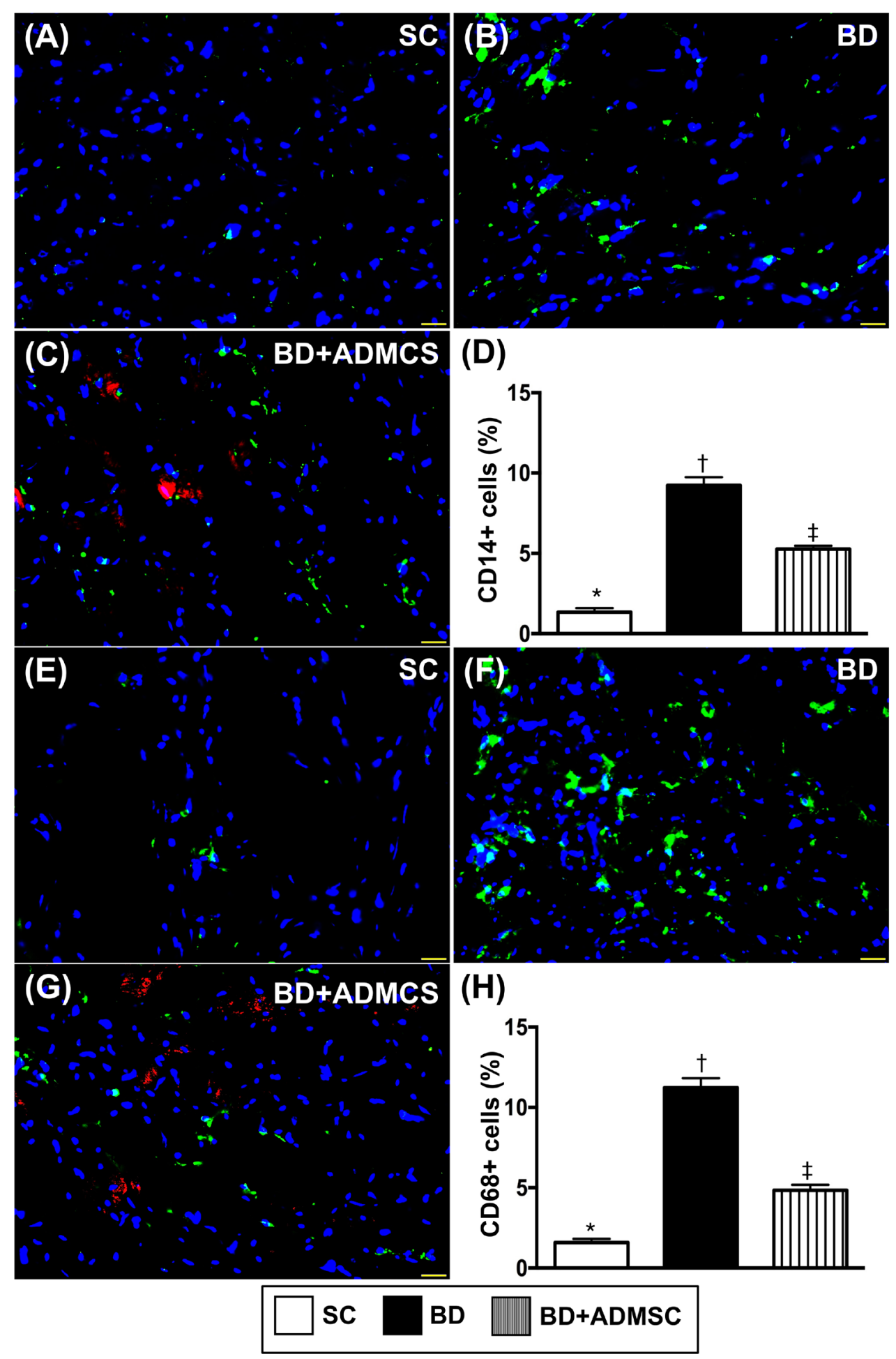

Figure 6: Cellular expressions of inflammatory biomarkers in kidney at $6 \mathrm{~h}$ after BD procedure. (A to C) Illustrating immunofluorescent (IF) microscopic finding (400x) for identifying CD14+ cells (green color). Red color in [4] indicated some Dil-dye positively-stained ADMSCs in heart tissue. (D) Analytical result of number of positively-stained CD cells, * vs. other bars with different symbols, $\mathrm{p}<0.0001$. (E to G) IF microscopic finding (400x) for identifying 68+ cells (green color). Red color in [4] indicated some Dildye positively-stained ADMSCs in heart tissue. H) Analytical result of number of positively-stained CD68+ cells, * vs. other groups with different symbols $(\dagger, \ddagger), \mathrm{p}<0.0001$. The scale bars in right lower corner represent $20 \mu \mathrm{m}$. All statistical analyses were performed by one-way ANOVA, followed by Bonferroni multiple comparison post hoc test $(\mathrm{n}=8)$. Symbols $(*, \dagger, \ddagger)$ indicate significance (at 0.05 level). $\mathrm{BD}=$ brain death; group $\mathrm{A} 1=$ sham control; group $\mathrm{A} 2$ = brain death; group $\mathrm{A} 3=$ brain death + adipose-derived mesenchymal stem cell (ADMSC). 
expressions of Smad1/5 and bone morphogenetic protein-2 (BMP-2), two indicators of anti-fibrosis, revealed an opposite pattern of Ly6G+ cells among the four groups (Figure 8).

\section{Protein expressions of inflammatory biomarkers in the transplanted heart by day 5 after BD procedure}

The protein expressions of TNF- $\alpha$, NF- $\kappa \mathrm{B}, \mathrm{MMP}-$ 9, IL-6 and macrophage inflammatory protein (MIP)$1 \alpha$, five indices of inflammation were highest in BD-T and lowest in $\mathrm{BD}-\mathrm{T}^{\mathrm{MSC}(3 \mathrm{~h}, \mathrm{D} 1 / 3)}$, and significantly higher in $\mathrm{BD}-\mathrm{T}^{\mathrm{MSC}(3 \mathrm{~h})}$ than in $\mathrm{BD}-\mathrm{T}^{\mathrm{MSC}(\mathrm{D} 1 / 3)}$. On the other hand, the protein expressions of IL-10 and IL-34 showed an opposite pattern of inflammatory biomarkers among the four groups (Figure 9).

\section{Histopathological findings and DNA-damage markers in transplanted heart by day 5 after BD procedure}

The light microscopic finding of hematoxylin and eosin (H\&E) stain showed that the integrity of myocardial architecture per high-power field was lowest in BD-T and highest in $\mathrm{BD}-\mathrm{T}^{\mathrm{MSC}(3 \mathrm{~h}, \mathrm{D} 1 / 3)}$, and significantly lower in BD$\mathrm{T}^{\mathrm{MSC}(3 \mathrm{~h})}$ than in $\mathrm{BD}-\mathrm{T}^{\mathrm{MSC}(\mathrm{D} 1 / 3)}$, shedding light on the impact of ADMSC treatment on suppressing the frequency of post-heart transplanted rejection. On the other hand, the cellular expression of $\gamma-\mathrm{H} 2 \mathrm{AX}+$ cells, an indicator of
(A)

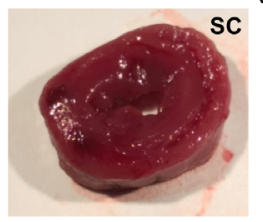

(A)

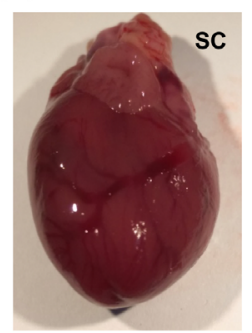

(G)

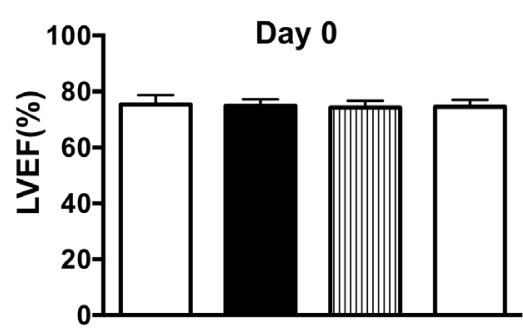

(B)

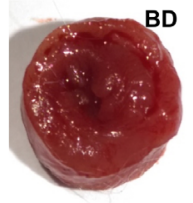

(B)

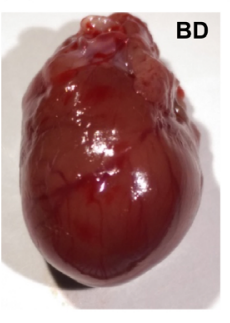

(C)
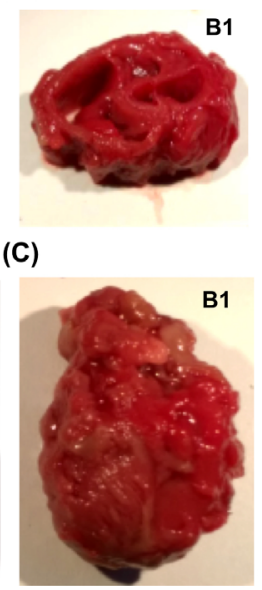

(D)

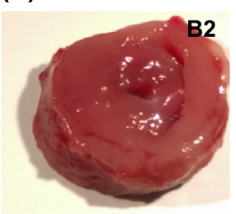

(E)

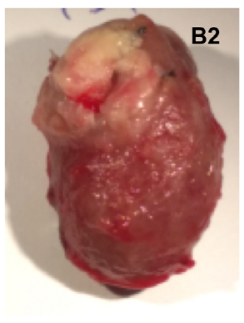

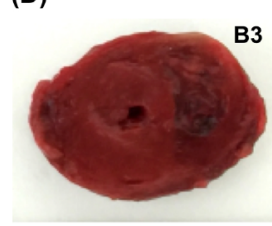

(D)

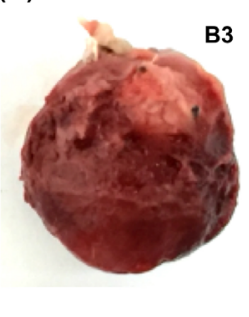

(F)

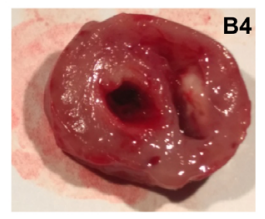

(F)

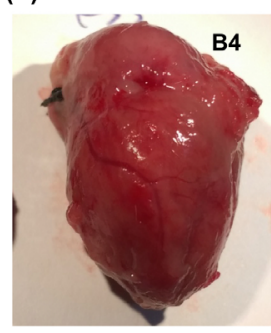

(H)
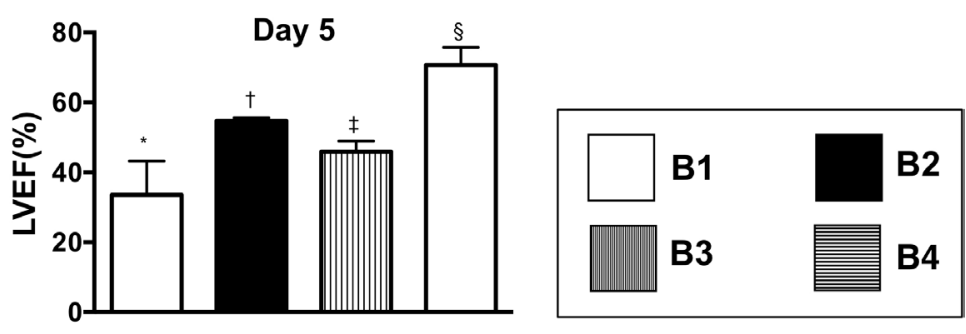

Figure 7: Anatomical-pathological findings and echocardiographic findings by day 5 after BD. (A to F) Illustration of anatomical-pathological findings of the hearts (i.e., whole heart and cross section) in groups: sham control (A), BD animal [1], donor heart of BD animal (i.e., Fischer344=F344) transplanted into recipient (i.e., Lewis) without treatment [4], F344 heart transplanted to Lewis + ADMSC administration at days 1 and 3 post-transplanted procedure (D), F344 heart transplanted to Lewis + ADMSC administration at $3 \mathrm{~h}$ after BD procedure (E), and F344 heart transplanted to Lewis + ADMSC administration at $3 \mathrm{~h}$ after BD and by days 1 and 3 after heart transplanted procedure [3]. The pathological findings showed that as compared with the other groups, the transplanted heart [4] was severely destroyed at day 5 after transplantation procedure, suggesting an occurrence of acute transplanted heart rejection. ( $\mathbf{G}$ and $\mathbf{H})$ Transthoracic echocardiographic findings for identification of left ventricular ejection fraction (LVEF). By day $0(\mathrm{G}): \mathrm{p}>0.5$. By day 5 [1], * vs. other groups with different symbols $(\dagger, \ddagger, \S), \mathrm{p}<0.0001$. All statistical analyses were performed by one-way ANOVA, followed by Bonferroni multiple comparison post hoc test ( $\mathrm{n}=8)$. Symbols (*, $\dagger, \ddagger$ ) indicate significance (at 0.05 level). B1 = F344 heart transplanted into Lewis by $6 \mathrm{~h}$ after BD; B2 = BD induction for $6 \mathrm{~h}$ followed by heart transplantation and ADMSC $\left(1.2 \times 10^{6}\right.$ cells $)$ transfused into recipient at days 1 and 3, respectively after transplantation; $\mathrm{B} 3=\mathrm{BD}+\mathrm{ADMSC}\left(1.2 \times 10^{6}\right.$ cells $)$ at $3 \mathrm{~h}$ and heart transplantation at $6 \mathrm{~h}$ after $\mathrm{BD} ; \mathrm{B} 4=\mathrm{BD}+\mathrm{ADMSC}\left(1.2 \times 10^{6}\right.$ cells) at $3 \mathrm{~h}$ and heart transplantation at $6 \mathrm{~h}$ after BD, followed by ADMSC $\left(1.2 \times 10^{6}\right.$ cells $)$ transfusion to recipient by days 1 and 3 , respectively after heart transplantation. $\mathrm{BD}=$ brain death; $\mathrm{ADMSC}=$ adipose-derived mesenchymal stem cell. 
DNA-damage, displayed an opposite pattern of integrity of myocardial architecture among the four groups (Figure 10).

\section{Cellular expressions of inflammatory biomarkers in transplanted heart by day 5 after BD procedure}

The immunofluorescence (IF) microscopic findings demonstrated that the number of $\mathrm{CD} 14+$ and F $4 / 80+$ cells, two indicators of inflammation, were higher in BD-T and

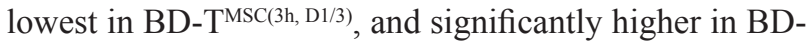
$\mathrm{T}^{\mathrm{MSC}(3 \mathrm{~h})}$ than in $\mathrm{BD}-\mathrm{T}^{\mathrm{MSC}(\mathrm{D} 1 / 3)}$ (Figure 11).

\section{Expression of immune cells in transplanted heart by day 5 after BD procedure}

Immunohistochemical (IHC) microscopic findings showed that the cellular expressions of $\mathrm{CD} 3+$ and $\mathrm{CD} 4+$ cells, two indicators of immune cells, were highest in $\mathrm{BD}-\mathrm{T}$ and lowest in $\mathrm{BD}-\mathrm{T}^{\mathrm{MSC}(3 \mathrm{~h}, \mathrm{D} 1 / 3)}$, and significantly higher in $\mathrm{BD}-\mathrm{T}^{\mathrm{MSC}(3 \mathrm{~h})}$ than in $\mathrm{BD}-\mathrm{T}^{\mathrm{MSC}(\mathrm{D} / / 3)}$ (Figure 12).

\section{DISCUSSION}

This study which investigated the impact of BD on remote organ damage and the therapeutic role of ADMSCs
(A)

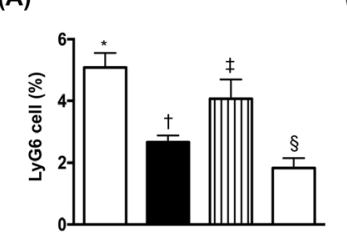

(F)

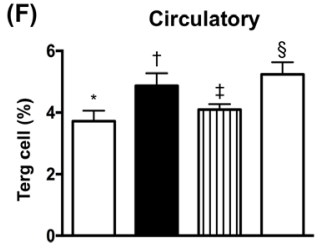

(B)

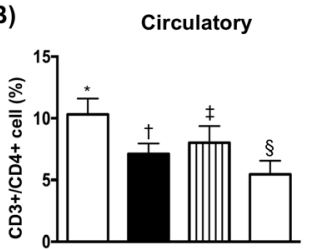

(G)

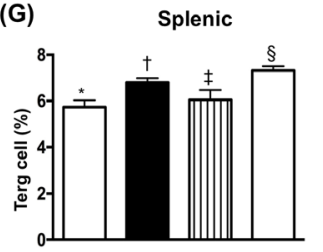

(C)

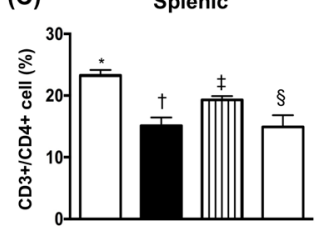

(H)

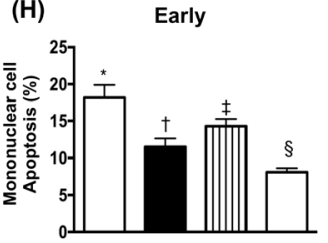

(D)
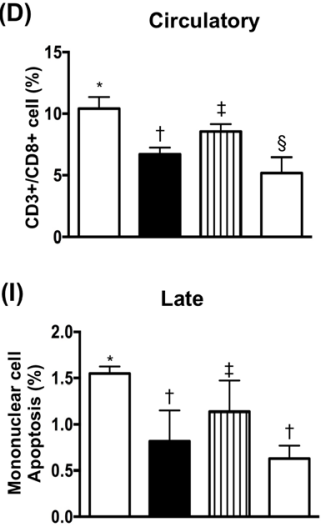

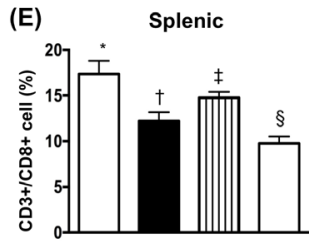

(J)

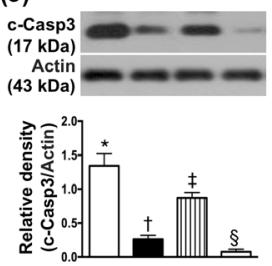

(K)

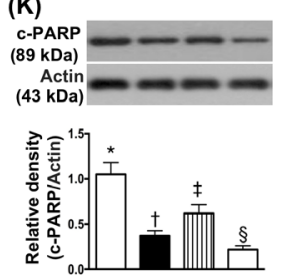

(L)

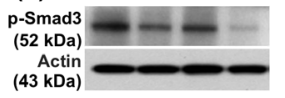

$(43 \mathrm{kDa})$

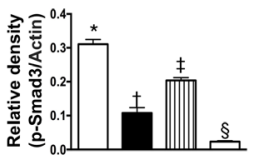

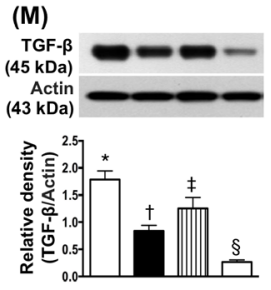

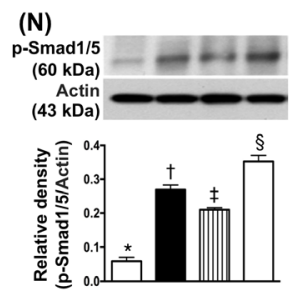

(O)

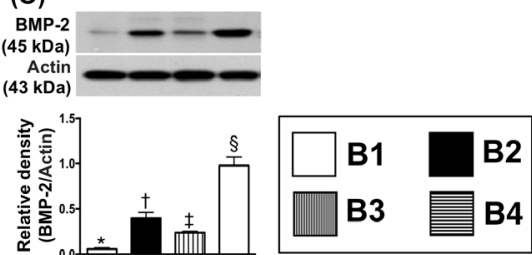

Figure 8: Flow cytometric analysis of inflammatory cells in circulation and spleen and the protein expressions of apoptotic, fibrotic and anti-fibrotic biomarkers by day 5 after heart transplantation. (A) Circulating level of Ly6G, * vs. other groups with different symbols $(\dagger,+, \S), \mathrm{p}<0.001$. (B) Circulating levels of CD3+/CD4+ cells, * vs. other groups with different symbols $(\dagger, \ddagger, \S), \mathrm{p}<0.001$. (C) Splenic levels of CD3+/CD4+ cells, $*$ vs. other groups with different symbols $(\dagger, \ddagger, \S)$, p<0.001. (D) Circulating levels of CD3+/CD8+ cells, ${ }^{*}$ vs. other groups with different symbols $(\dagger, \$, \S), \mathrm{p}<0.001$. (E) Splenic levels of CD3+/CD8+ cells, * vs. other groups with different symbols $(\dagger, \$, \S), \mathrm{p}<0.001$. (F) Circulating levels of Treg cells (CD4+CD25+Foxp3+ cells), $*$ vs. other bars with different symbols $(\dagger, \ddagger \S \S), \mathrm{p}<0.001$. (G) Splenic levels of Treg cells, * vs. other groups with different symbols $(\dagger, \ddagger$, $)$, $\mathrm{p}<0.001, \mathrm{p}<0.001$. (H) Early apoptosis, * vs. other groups with different symbols $(\dagger, \uparrow, \S), \mathrm{p}<0.001$. (I) Late apoptosis, * vs. other groups with different symbols $(\dagger, \ddagger), \mathrm{p}<0.001$. (J) Protein expression of cleaved caspase 3 (c-Casp 3 ), * vs. other groups with different symbols $(\dagger,+, \S), \mathrm{p}<0.0001$. (K) Protein expression of cleaved poly (ADP-ribose) polymerase (c-PARP), * vs. other groups with different symbols $(\dagger, \dagger, \S), \mathrm{p}<0.0001$. (L) Protein expression of phosphorylated (p)-Smad3, * vs. other groups with different symbols $(\dagger, \ddagger, \S), \mathrm{p}<0.0001$. (M) Protein expression of transforming growth factor (TGF) $-\beta, *$ vs. other groups with different symbols $(\dagger, \ddagger$, $)$, p $<0.0001$. (N) Protein expression of $\mathrm{p}-\mathrm{Smad} 1 / 5, *$ vs. other groups with different symbols $(\dagger, \downarrow, \S), \mathrm{p}<0.0001$. (O) Protein expression of bone morphogenetic protein (BMP)-2,* vs. other groups with different symbols $(\dagger, \ddagger, \S), \mathrm{p}<0.0001$. All statistical analyses were performed by one-way ANOVA, followed by Bonferroni multiple comparison post hoc test $(\mathrm{n}=8)$. Symbols $(*, \uparrow, \$$, $)$ indicate significance (at 0.05 level). B1 $=$ F344 heart transplanted into Lewis by $6 \mathrm{~h}$ after BD; B2 = BD induction for $6 \mathrm{~h}$ followed by heart transplantation and ADMSC (1.2x10 ${ }^{6}$ cells) transfused into recipient at days 1 and 3 , respectively after transplantation; B3 $=\mathrm{BD}+\mathrm{ADMSC}\left(1.2 \times 10^{6}\right.$ cells $)$ at $3 \mathrm{~h}$ and heart transplantation at $6 \mathrm{~h}$ after $\mathrm{BD} ; \mathrm{B} 4=\mathrm{BD}+\mathrm{ADMSC}\left(1.2 \times 10^{6}\right.$ cells $)$ at $3 \mathrm{~h}$ and heart transplantation at $6 \mathrm{~h}$ after $\mathrm{BD}$, followed by ADMSC $\left(1.2 \times 10^{6}\right.$ cells $)$ transfusion to recipient by days 1 and 3 , respectively after heart transplantation. $\mathrm{BD}=$ brain death; $\mathrm{ADMSC}=$ adiposederived mesenchymal stem cell. 
in protecting $\mathrm{BD}$-induced remote organ damage and the transplanted heart from graft versus host disease yielded several striking results. Frist, BD was identified not only to elicit inflammatory/immune reactions but also to cause remote organ damage. Second, allogenic ADMSC therapy markedly suppressed $\mathrm{BD}$-caused remote organ damage. Third, allogenic ADMSC therapy protected the transplanted heart from graft versus host disease.

Intriguingly, experimental studies have shown that a vigorous inflammatory reaction and hyper-reactive immune response frequently occur in major organs of BD animals [34-36]. Another essential finding in the present study was that the protein levels of inflammation in the brain and both protein and cellular levels of inflammation in three major organs (i.e., liver, kidney and heart) were substantially enhanced in the BD group as compared to the control group. However, these molecular-cellular perturbations were remarkably attenuated in BD animals after receiving ADMSC treatment. Our findings, therefore, in addition to reinforcing the findings from previous studies [34-36], highlight the potential role of MSC therapy in clinical settings of graft versus host disease.

It is well known that the legal donors for heart transplantation are always $\mathrm{BD}$ victims. The donor heart is a precious gift for the recipient. Interestingly, not only inflammatory and immune reactions but also heart failure biomarkers have been identified to be markedly increased in setting of IS [22-28]. Additionally, an association between more severe brain damage and vigorous inflammatory/immune responses [23, 29, 32-36] as well as lower LVEF $[22,23]$ has been clearly established by previous studies [22-29, 32-37]. An essential finding in the present study was that the circulating and splenic levels of inflammatory/immune reactions were found to be remarkably increased in BD animals as compared with the control animals. Our findings were comparable with the findings of the previous studies [23, 29, 3236]. Importantly, these circulating and splenic levels of
(A)

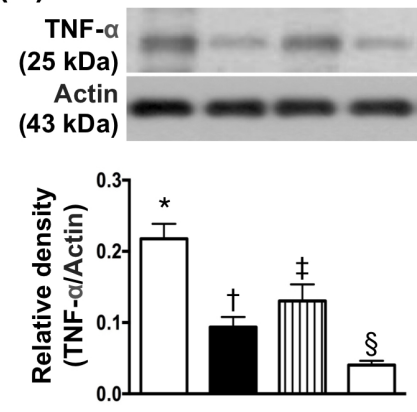

(E)
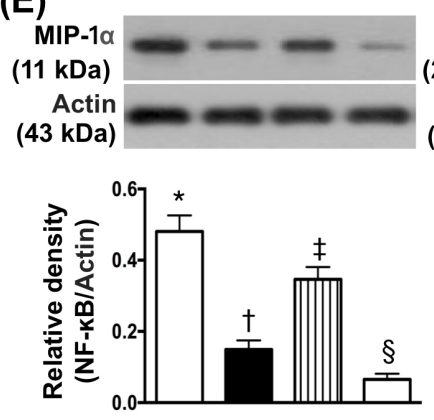

(B)
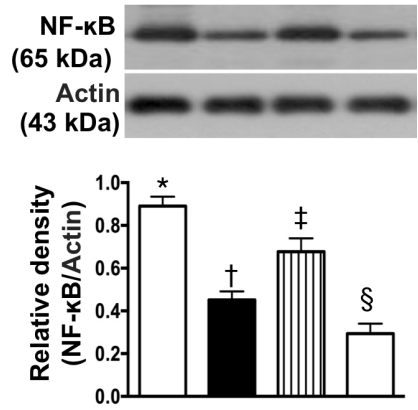

(F)
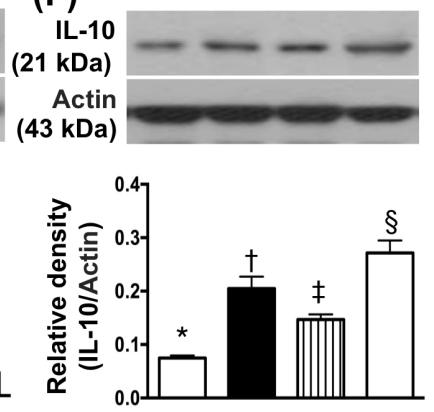

(C)
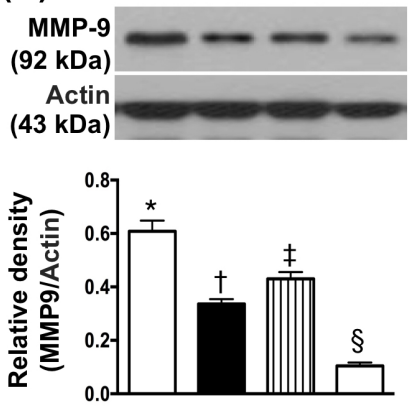

(G)
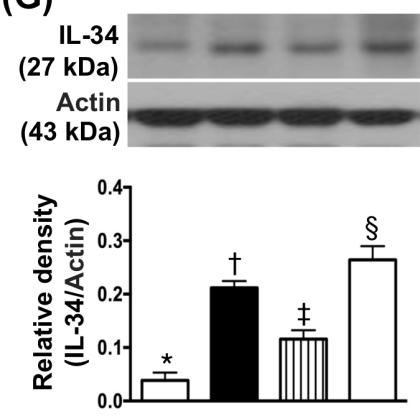

(D)

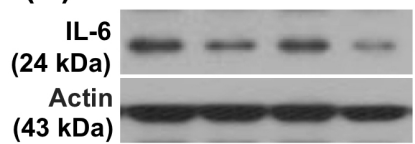

(43 kDa)

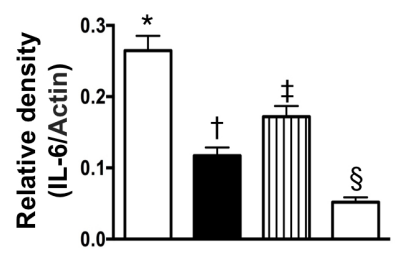

Figure 9: Protein expressions of inflammatory biomarkers in transplanted heart by day 5 after heart transplantation. (A) Protein expression of tumor necrosis factor (TNF)- $\alpha$, * vs. other groups with different symbols $(\dagger, \uparrow, \S)$, p $<0.001$. (B) Protein expression of nuclear factor (NF)- $\kappa B, *$ vs. other groups with different symbols $(\dagger, t, \S), \mathrm{p}<0.0001$. (C) Protein expression of matrix metalloproteinase (MMP)-9, * vs. other groups with different symbols $(\dagger, \ddagger, \S), \mathrm{p}<0.0001$. (D) Protein expression of interleukin [6]-6, * vs. other groups with different symbols $(\dagger, \uparrow, \S), \mathrm{p}<0.0001$. (E) Protein expression of macrophage inflammatory protein (MIP)-1 $\alpha$, * vs. other groups with different symbols $(\dagger, \ddagger, \S), \mathrm{p}<0.0001$. (F) Protein expression of IL-10, * vs. other groups with different symbols $(\dagger, \downarrow$, $\S), \mathrm{p}<0.0001 .(\mathbf{G})$ Protein expression of IL-34, * vs. other groups with different symbols $(\dagger, \ddagger, \S), \mathrm{p}<0.0001$. All statistical analyses were performed by oneway ANOVA, followed by Bonferroni multiple comparison post hoc test $(\mathrm{n}=8)$. Symbols $(*, \dagger, \ddagger$, $)$ indicate significance (at 0.05 level). B1 $=\mathrm{F} 344$ heart transplanted into Lewis by $6 \mathrm{~h}$ after BD; B2 $=\mathrm{BD}$ induction for $6 \mathrm{~h}$ followed by heart transplantation and ADMSC $\left(1.2 \times 10^{6}\right.$ cells) transfused into recipient at days 1 and 3 , respectively after transplantation; B3 $=\mathrm{BD}+\mathrm{ADMSC}\left(1.2 \times 10^{6}\right.$ cells $)$ at $3 \mathrm{~h}$ and heart transplantation at $6 \mathrm{~h}$ after $\mathrm{BD} ; \mathrm{B} 4=\mathrm{BD}+\mathrm{ADMSC}\left(1.2 \times 10^{6}\right.$ cells $)$ at $3 \mathrm{~h}$ and heart transplantation at $6 \mathrm{~h}$ after BD, followed by ADMSC $\left(1.2 \times 10^{6}\right.$ cells $)$ transfusion to recipient by days 1 and 3 , respectively after heart transplantation. $\mathrm{BD}=$ brain death; ADMSC $=$ adiposederived mesenchymal stem cell. 
inflammatory and immune biomarkers were notably suppressed in BD animals after receiving ADMSC treatment. Our findings extended the findings of the previous studies [23, 29, 32-36].

Despite state-of-the-art in advances of pharmacomodulation and refinement of the immunosuppressant regimen for heart transplant patients, an effective method for resolving the occurrence of postheart transplanted rejection is still lacking. Intriguingly, limited data have previously demonstrated that pretransplant administration of MSCs can prolong the survival of allogeneic heart transplant through the generation of regulatory $\mathrm{T}$ cells and immune tolerance $[50,51]$. A principal finding in the present study is that as
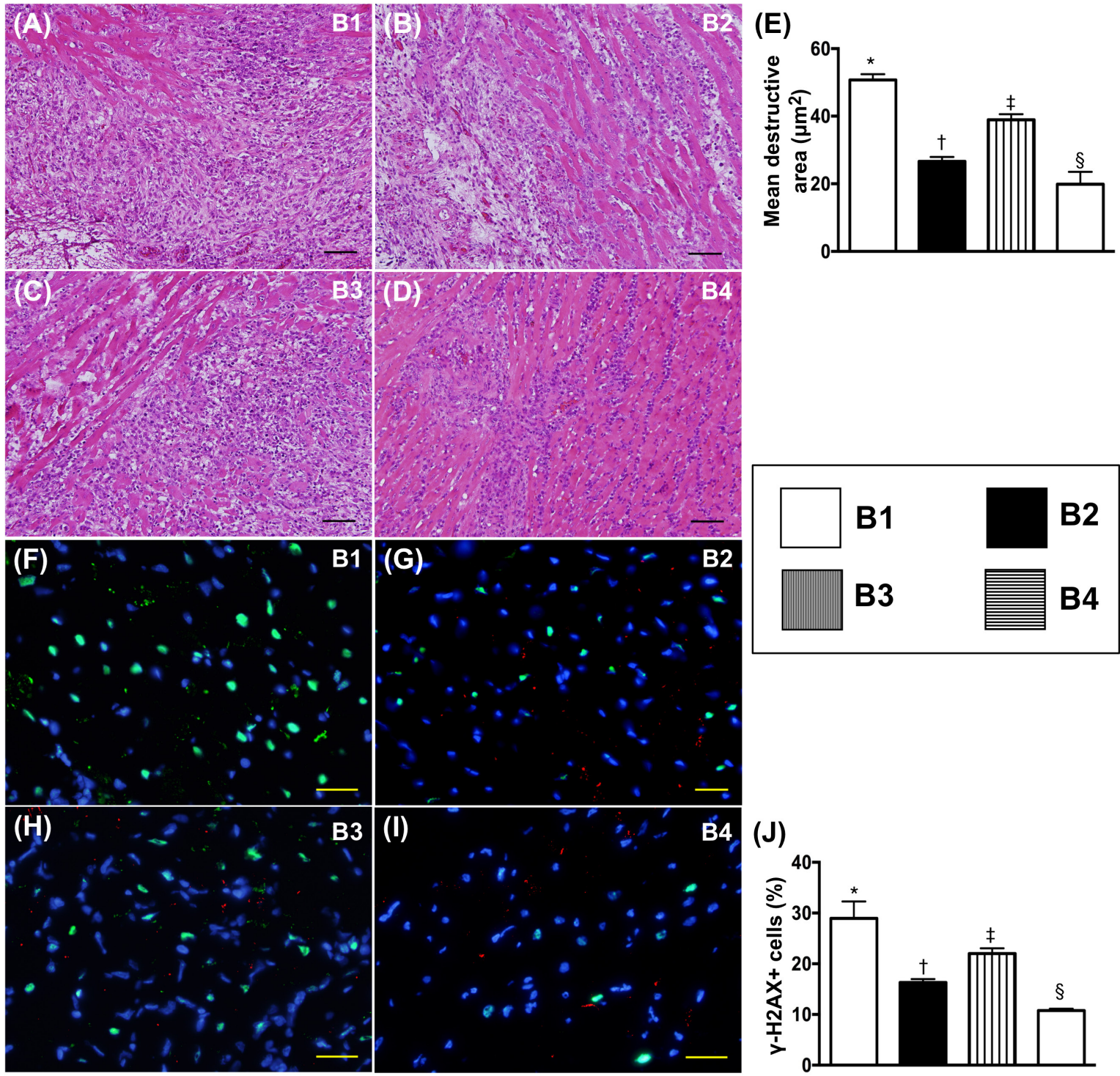

Figure 10: Histopathological finding and DNA-damaged marker in transplanted heart by day 5 after heart transplantation. (A to D) Illustrating the light microscopic finding (100x) of H \& E stain for identifying the destructive area (bluecolored fibrotic area). The scale bars in right lower corner represent $100 \mu \mathrm{m}$. (E) Analytic result of the destructive area, * vs. other groups with different symbols $(\dagger, \$, \S), \mathrm{p}<0.0001$. (F to I) Illustrating the microscopic finding (400x) of immunofluorescent stain for identification of $\gamma-\mathrm{H} 2 \mathrm{AX}+$ cells (green color). The scale bars in right lower corner represent $20 \mu \mathrm{m}$. (J) Analytic results of number of positively-stained $\gamma$-H2AX cells, * vs. other groups with different symbols $(\dagger,+\S), \mathrm{p}<0.0001$. All statistical analyses were performed by one-way ANOVA, followed by Bonferroni multiple comparison post hoc test $(n=8)$. Symbols $(*, \uparrow, \uparrow$, $)$ indicate significance $($ at 0.05 level $)$. B1 $=$ F344 heart transplanted into Lewis by $6 \mathrm{~h}$ after $\mathrm{BD} ; \mathrm{B} 2=\mathrm{BD}$ induction for $6 \mathrm{~h}$ followed by heart transplantation and ADMSC $\left(1.2 \times 10^{6}\right.$ cells $)$ transfused into recipient at days 1 and 3, respectively after transplantation; B3 $=\mathrm{BD}+\mathrm{ADMSC}\left(1.2 \times 10^{6} \mathrm{cells}\right)$ at $3 \mathrm{~h}$ and heart transplantation at $6 \mathrm{~h}$ after $\mathrm{BD} ; \mathrm{B} 4=\mathrm{BD}+\mathrm{ADMSC}\left(1.2 \times 10^{6}\right.$ cells $)$ at $3 \mathrm{~h}$ and heart transplantation at $6 \mathrm{~h}$ after $\mathrm{BD}$, followed by ADMSC $\left(1.2 \times 10^{6}\right.$ cells $)$ transfusion to recipient by days 1 and 3, respectively after heart transplantation. $\mathrm{BD}=$ brain death; $\mathrm{ADMSC}$ = adipose-derived mesenchymal stem cell. 
compared with allograft animals without treatment, preheart transplantation of ADMSC transfusion preserved the integrity of donor heart architecture after transplantation. The finding of the present study was supported by previous studies $[50,51]$. Another principal finding in the present study was that post-heart transplanted ADMSC therapy further protected the donor heart from acute rejection damage. The most important finding in the present study was that pre- and post-heart transplant ADMSC treatment offered a further protective effect on the donor heart. In addition to extending the results of previous studies [50, 51], our findings highlight the need for a prospective clinical trial to test the safety and efficacy of MSC therapy for prolonged heart allograft survival.

\section{Study limitations}

This study has some limitations. First, the impact of allogenic ADMSC on protecting the remote organs (i.e., heart, liver and kidney) against the $\mathrm{BD}$-induced damage
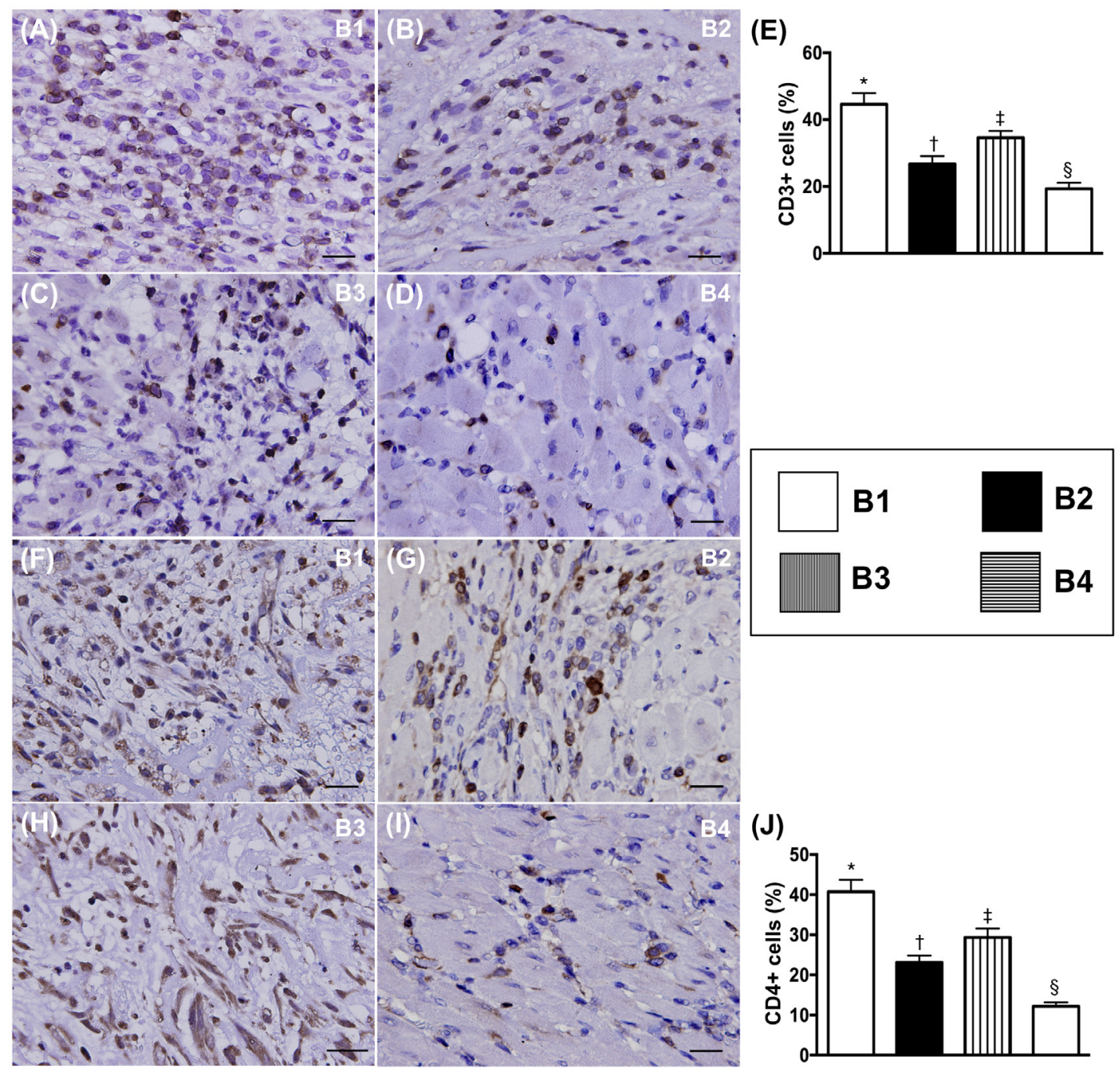

Figure 11: Immune cell expression in transplanted heart by day 5 after heart transplantation. (A to D) Illustrating microscopic finding (400x) of immunohistochemical (IHC) staining for identification of CD3+ cells (gray color). (E) Analytical results of number of positively-stained CD3 cells, * vs. other groups with different symbols $(\dagger, \$, \S), \mathrm{p}<0.001$. (F to I) Illustrating microscopic finding of IHC staining for identification of CD4+ cells (gray color). (J) Analytical results of number of positively-stained CD4 cells, * vs. other groups with different symbols $(\dagger, \ddagger, \S), \mathrm{p}<0.001$. The scale bars in right lower corner represent $20 \mu \mathrm{m}$. All statistical analyses were performed by one-way ANOVA, followed by Bonferroni multiple comparison post hoc test $(\mathrm{n}=8)$. Symbols $(*, \dagger, \uparrow$, $\S)$ indicate significance (at 0.05 level). B1 = F344 heart transplanted into Lewis by $6 \mathrm{~h}$ after BD; B2 = BD induction for $6 \mathrm{~h}$ followed by heart transplantation and $\operatorname{ADMSC}\left(1.2 \times 10^{6}\right.$ cells $)$ transfused into recipient at days 1 and 3 , respectively after transplantation; $\mathrm{B} 3=\mathrm{BD}+\mathrm{ADMSC}\left(1.2 \times 10^{6}\right.$ cells $)$ at $3 \mathrm{~h}$ and heart transplantation at $6 \mathrm{~h}$ after BD; B4 $=\mathrm{BD}+\mathrm{ADMSC}\left(1.2 \times 10^{6}\right.$ cells $)$ at $3 \mathrm{~h}$ and heart transplantation at $6 \mathrm{~h}$ after BD, followed by $\operatorname{ADMSC}\left(1.2 \times 10^{6}\right.$ cells $)$ transfusion to recipient by days 1 and 3 , respectively after heart transplantation. $\mathrm{BD}=$ brain death; $\mathrm{ADMSC}=$ adipose-derived mesenchymal stem cell. 
and transplanted heart against acute graft versus host disease was only studied for a period of 5 days. Thus, we do not know the long-term effect of ADMSCs on protecting these organs. Second, immunosuppressant drugs such as cyclosporine or tacrolimus were not utilized in the current study. Thus, we do not know whether combined therapy with ADMSC and immunosuppressant drugs are superior to either one for protecting the transplanted heart against graft versus host disease, especially when the long-term heart transplantation outcome is taken into consideration.

In conclusion, the results of the present study demonstrated that allogenic ADMSC therapy significantly protected against BD-induced remote organ damage
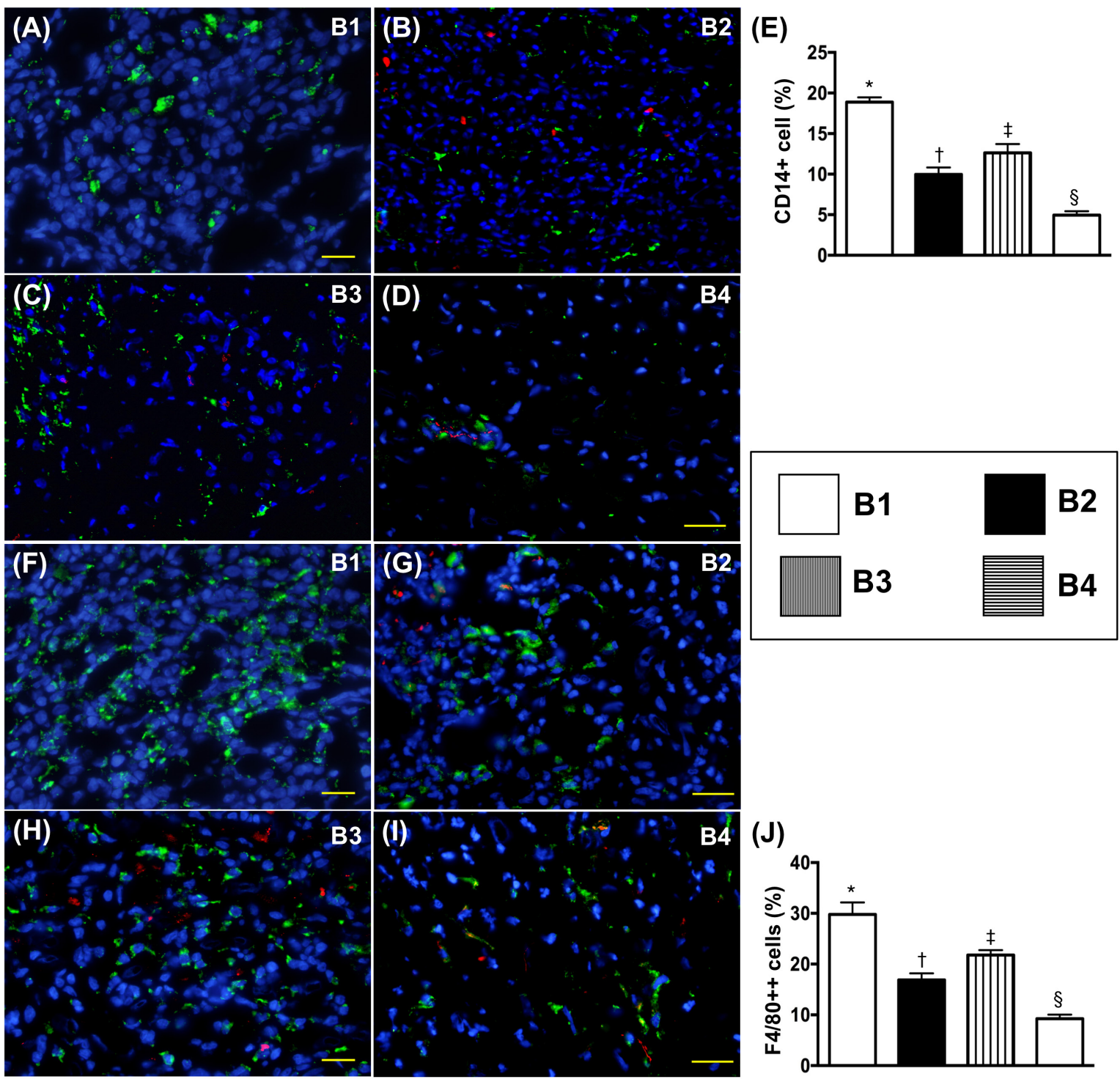

Figure 12: Cellular expressions of inflammatory biomarkers in transplanted heart by day 5 after heart transplantation. (A to D) Illustrating microscopic finding (400x) of immunofluorescent (IF) staining for identification of CD14+ cells (green color). Red color in (B, C, D) indicated some Dil-dye positively-stained ADMSCs in heart tissue. (E) Analytical results of number of positivelystained CD14 cells, * vs. other groups with different symbols $(\dagger, \$, \S), \mathrm{p}<0.0001$. (F to I) Illustrating microscopic finding of IF staining for identification of F4/80+ cells (green color). Red color in (G, H, I) indicated some Dil-dye positively-stained ADMSCs in heart tissue. (J) Analytical results of number of positively-stained F4/80 cells, * vs. other groups with different symbols $(\dagger, \ddagger, \S)$, p $<0.0001$. The scale bars in right lower corner represent $20 \mu \mathrm{m}$. All statistical analyses were performed by one-way ANOVA, followed by Bonferroni multiple comparison post hoc test $(\mathrm{n}=8)$. Symbols $(*, \dagger, \$, \S)$ indicate significance (at 0.05 level). B1 = F344 heart transplanted into Lewis by $6 \mathrm{~h}$ after BD; B2 = BD induction for $6 \mathrm{~h}$ followed by heart transplantation and ADMSC $\left(1.2 \times 10^{6}\right.$ cells $)$ transfused into recipient at days 1 and 3 , respectively after transplantation; $\mathrm{B} 3=\mathrm{BD}+\mathrm{ADMSC}\left(1.2 \times 10^{6}\right.$ cells $)$ at $3 \mathrm{~h}$ and heart transplantation at $6 \mathrm{~h}$ after $\mathrm{BD} ; \mathrm{B} 4=\mathrm{BD}+\mathrm{ADMSC}$ $\left(1.2 \times 10^{6}\right.$ cells $)$ at $3 \mathrm{~h}$ and heart transplantation at $6 \mathrm{~h}$ after $\mathrm{BD}$, followed by ADMSC $\left(1.2 \times 10^{6}\right.$ cells $)$ transfusion to recipient by days 1 and 3 , respectively after heart transplantation. $\mathrm{BD}=$ brain death; $\mathrm{ADMSC}=$ adipose-derived mesenchymal stem cell. 
mainly through suppressing the inflammatory immune reactions. Additionally, allogenic AMDSC treatment reduced acute graft versus host injury in the transplanted heart, suggesting that MSCs may play an important accessory role as an immunosuppressant drug to reduce the occurrence of post-heart transplantation rejection.

\section{MATERIALS AND METHODS}

\section{Ethics}

All animal experimental procedures were approved by the Institute of Animal Care and Use Committee at Kaohsiung Chang Gung Memorial Hospital (Affidavit of Approval of Animal Use Protocol No. 2011053001) and performed in accordance with the Guide for the Care and Use of Laboratory Animals [The Eighth Edition of the Guide for the Care and Use of Laboratory Animals (NRC 2011)].

Animals were housed in an Association for Assessment and Accreditation of Laboratory Animal Care International (AAALAC)-approved animal facility in our hospital with controlled temperature and light cycle $\left(24^{\circ} \mathrm{C}\right.$ and 12/12 light cycle).

\section{Induction of brain death in the animal model (referred to Figure 1)}

For induction of brain death, animals in each group were anesthetized by inhalational of $2.0 \%$ isoflurane on a warming pad at $37^{\circ} \mathrm{C}$ and were placed in the prone position as previously described [52] with slight modifications to mimic the clinical scenario of sudden-onset increase in intracranial pressure as in severe traumatic intra-cranial hemorrhage that results in brain-stem failure. Following an incision made on the skin covering the skull and dissection of the epicranial muscles and periosteum, a $4 \mathrm{~F}$ angioplasty balloon catheter was carefully introduced into the supradural space inside the cranial cavity of the rat through a blur hole on the skull at the paramedian space near the frontal transverse sinus made with a dental drill. Each animal was endotracheally intubated with positivepressure ventilation $(180 \mathrm{~mL} / \mathrm{min})$ with room air using a small animal ventilator (SAR-830/A, CWE Inc., U.S.A.) at a ventilation rate of about $60 / \mathrm{min}$ and $\mathrm{BD}$ was induced by injecting $0.5 \mathrm{~mL}$ of distilled water through the catheter into the supradurally implanted balloon. Heart rate and blood pressure were continuously monitored during the whole procedure.

\section{Criteria for identification of BD in animals (referred to Figure 1)}

BD manifested as an immediate and significant reduction in system arterial blood pressure (SBAP) and the power density of low-frequency (LF) components of SABP and had to include the following criteria:

1. Cessation of spontaneous respiration (i.e., complete dependence on mechanical ventilation)

2. Irreversible deep coma (i.e., lack of response and reflex to pain elicited by pinching the foot with forceps)

3. Fixed and dilated pupils without light reflex regardless of the intensity of light (i.e., fixed and dilated pupils without reflex to light)

The sum of power density during the period of the low-frequency (LF; $0.25-0.8 \mathrm{~Hz}$ in rat) components in the blood pressure (BP) and heart rate (HR) spectra, along with the average values and of mean $\mathrm{BP}$ and $\mathrm{HR}$ were computerized in the present study [53-55].

\section{Animal grouping}

To determine the impact of $\mathrm{BD}$ on remote organ damage, pathogen-free, adult male Fischer344 (F344) rats $(\mathrm{n}=24)$ weighing 250-280 g (Charles River Technology, BioLASCO Taiwan Co. Ltd., Taiwan) were utilized in the present study. These animals were randomly divided into three groups: sham-control $(\mathrm{SC}), \mathrm{BD}$ and $\mathrm{BD}^{\mathrm{MSC}}$ $\left[\mathrm{BD}+\right.$ allogenic ADMSC $\left(1.2 \times 10^{6}\right.$ cells: derived from other additional F344 (i.e., the donors for ADMSC) by intravenous transfusion $3 \mathrm{~h}$ after BD procedure)].

To elucidate the protective effect of allogenic ADMSC on transplanted heart against post-transplant rejection, animals ( $n=8$ in each group of F344 and Lewis) were categorized into four groups: BD-T [F344 heart (i.e., donor) was transplanted into Lewis (i.e., recipient) by $6 \mathrm{~h}$ after $\mathrm{BD}$ ], BD-T ${ }^{\mathrm{MSC}(\mathrm{D} 1 / 3)}$ [BD induction in $\mathrm{F} 344$ for $6 \mathrm{~h}$ followed by F344 heart transplanted into Lewis and allogenic ADMSCs $\left(1.2 \times 10^{6}\right.$ cell/each time) (i.e., ADMSCs from F344 donor) were transfused into Lewis (i.e., recipient) at days 1 and 3 after heart transplantation),

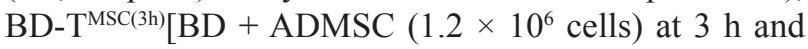
heart transplantation at $6 \mathrm{~h}$ after $\mathrm{BD}]$, and $\mathrm{BD}-\mathrm{T}^{\mathrm{MSC}(3 \mathrm{~h} \text {, }}$ $\left.{ }^{\mathrm{D} 1 / 3}\right)\left[\mathrm{BD}+\mathrm{ADMSC}\left(1.2 \times 10^{6}\right.\right.$ cells $)$ at $3 \mathrm{~h}$ and heart transplantation at $6 \mathrm{~h}$ after $\mathrm{BD}$, followed by ADMSC therapy to recipient by days 1 and 3 after transplantation procedure]. All of the animals were euthanized and the hearts were harvested by day 5 after heart transplanted procedure for individual study.

\section{Procedure and protocol of heart transplantation}

\section{Stage 1}

1. After being anesthetized with $2 \%$ inhalational isoflurane, the recipient rat (i.e., Lewis) was placed in a supine position with its four limbs secured on the operation table with adhesive tape.

2. A midline skin incision was made vertically between the mandible and the sternal notch. 
3. The external jugular vein was identified and dissected from the surrounding tissue until a length between 0.5 and $1.0 \mathrm{~cm}$ was free. The side branches of the vein were ligated and divided, while the vein was clamped proximal with a vascular clip.

4. The isolated vein was then inserted through a segment of $18 \mathrm{G}$ plastic venous catheter of length $1.5-2.0 \mathrm{~mm}$ that serves as a cuff. The portion of vein that passed through the cuff was turned inside out to cover the cuff on which a piece of 6-0 silk was used to secure the venous segment on the cuff.

5. The ipsilateral internal carotid artery was identified and dissected free from the surrounding structures until a length of $0.5-1.0 \mathrm{~cm}$ was freed. While the proximal part of the arterial segment was clamped with a vascular clip, it was ligated and divided distally.

6. The dissected artery was then inserted through a segment of $22 \mathrm{G}$ plastic venous catheter of length 1.5$2.0 \mathrm{~mm}$ that serves as a cuff. The portion of the artery that passed through the cuff was turned inside out to cover the cuff on which a piece of 6-0 silk was tied to secure the arterial segment on the cuff.

\section{Stage 2}

1. After being anesthetized with $2 \%$ isoflurane, a midline abdominal incision was made on the donor rat (i.e., F344) between the xyphoid process and the symphysis pubis. The infra-hepatic vena cave was identified to which $10 \mathrm{~mL}$ physiological saline with $10 \%$ heparin was infused. The heart was exposed by opening up the thoracic cavity with a midline incision through the sternum. After moistening the heart with $0.5 \mathrm{~mL}$ heparinized saline, the aorta and pulmonary arteries were dissected free from the surrounding structures and divided. The heart graft was harvested after ligation of the superior and inferior vena cava as well as the pulmonary veins.

2. The heart graft was placed on the neck of the recipient rat next to the recipient vessels to be anastomized and was kept moist with normal saline. The dissected segment of the internal carotid artery of the recipient was inserted into the aorta of the heart graft. A piece of 6-0 silk was tied over the inserted segment. Similarly, the dissected segment of the external jugular vein was inserted into the pulmonary artery of the heart graft, followed by securing the anastomosis by tying with a piece of 6-0 silk. The vascular clips on the external jugular vein and internal carotid artery of the recipient were then removed to allow perfusion and resumption of beating of the heart graft.

3. Following placement of the heart graft back to the neck, the skin of the neck was closed with 5-0 Nylon. The recipient rat was allowed to recover from anesthesia in a portable animal intensive care unit (ThermoCare) for 24 hours.

\section{Isolation of adipose tissue from additional 24 F344 for culturing ADMSCs}

The procedure and protocol for ADMSC isolation and culturing have been described in our previous reports [42-44, 49]. Briefly, animals (i.e., additional F344) were anesthetized with inhalational $2.0 \%$ isoflurane 14 days before the BD procedure to harvest the adipose tissue surrounding the epididymis. Then $200-300 \mu \mathrm{L}$ of sterile saline was added to every $0.5 \mathrm{~g}$ of adipose tissue to prevent dehydration. The tissue was then cut into $<1 \mathrm{~mm}^{3}$ size pieces using a pair of sharp, sterile surgical scissors. Sterile saline $\left(37^{\circ} \mathrm{C}\right)$ was added to the homogenized adipose tissue in a ratio of 3:1 (saline: adipose tissue) by volume. Isolated allogenic ADMSCs were cultured in a $100 \mathrm{~mm}$ diameter dish with $10 \mathrm{~mL}$ DMEM culture medium containing $10 \%$ FBS for 14 days.

\section{Collection of blood samples and specimens of major organs for specific studies}

The blood samples were collected prior to and at 6 and $48 \mathrm{~h}$ after $\mathrm{BD}$ induction to measure the $\mathrm{CD} 3 / \mathrm{CD}^{+}$, $\mathrm{CD} 8 / \mathrm{CD}^{+}, \mathrm{Treg}^{+}$and $\mathrm{LY} 6 \mathrm{G}^{+}$cells by flow cytometry, and plasma levels of TNF- $\alpha$, IL- $\beta$, IL- 6 and MPO using ELISA assessment. Additionally, blood samples were collected from the spleen prior to euthanizing the animals for analysis of immune cells $\left(\mathrm{CD} 3 / \mathrm{CD}^{+}, \mathrm{CD} 8 / \mathrm{CD}^{+}, \mathrm{Treg}^{+}\right)$.

\section{Flow cytometric quantification of helper $T$ cells and cytotoxic $T$ cells}

The procedure and protocol of flow cytometry for identification and quantification of circulating and splenic immune cells were based on our previous report [44]. Briefly, the peripheral blood mononuclear cells (PBMCs) and splenocytes were obtained from the tail vein using a $27 \#$ needle. PBMCs and splenocytes $\left(1.0 \times 10^{6}\right.$ cells $)$ were triple-stained with FITC-anti-CD3 (BioLegend), PEanti-CD8a (BD Bioscience), and PE-Cy ${ }^{\mathrm{TM}} 5$ anti-CD4 (BD bioscience). The numbers of $\mathrm{CD}^{+}{ }^{+} \mathrm{CD} 4^{+}$helper $\mathrm{T}$ cells and $\mathrm{CD}^{+} \mathrm{CD}^{+}$cytotoxic $\mathrm{T}$ cells were analyzed using flow cytometry (FC500, Beckman Coulter).

\section{Immunohistochemical (IHC) and immunofluorescent (IF) staining}

The procedure and protocol of IF staining have been described in details in our previous reports [42-44, 49]. For IHC and IF staining, rehydrated paraffin sections were first treated with $3 \% \mathrm{H}_{2} \mathrm{O}_{2}$ for 30 minutes and incubated with Immuno-Block reagent (BioSB) for 30 minutes at room temperature. Sections were then incubated with primary antibodies specifically against F4/80 (1:100, Abcam), CD14 (1:300, Bioss), CD68 (1:100, Abcam), CD69 (1:400, Gene Tex), CD3 (1:400, Abcam), CD4 (1:200, 
Novus Biologicals) and $\gamma$-H2AX (1:500, Abcam) while sections incubated with the use of irrelevant antibodies served as controls. Three sections of liver specimen from each rat were analyzed. For quantification, three randomly selected HPFs (200x or 400x for IHC and IF studies) were analyzed in each section. The mean number of positivelystained cells per HPF for each animal was then determined by summation of all numbers divided by 9 .

\section{Western blot analysis}

The procedure and protocol for Western blot analysis were based on our recent reports [42-44, 49]. In details, equal amounts $(50 \mu \mathrm{g})$ of protein extracts were loaded and separated by SDS-PAGE using acrylamide gradients. After electrophoresis, the separated proteins were transferred electrophoretically to a polyvinylidene difluoride (PVDF) membrane (Amersham Biosciences). Nonspecific sites were blocked by incubation of the membrane in blocking buffer [5\% nonfat dry milk in T-TBS (TBS containing $0.05 \%$ Tween 20 )] overnight. The membranes were incubated with the indicated primary antibodies [cleaved poly (ADP-ribose) polymerase (PARP) (1:1000, Cell Signaling), phosphorylated (p)-Smad3 (1:1000, Cell Signaling), p-Smad1/5 (1:1000, Cell Signaling), transforming growth factor (TGF)- $\beta$ (1:500, Abcam), bone morphogenetic protein (BMP)-2 (1:500, Abcam), TNF- $\alpha$ (1:1000, Cell Signaling), nuclear factor (NF)-кB (1:600, Abcam), interleukin [6]-1 $\beta$ (1:1000, Cell Signaling), IL-6 (1:750, Abcam), high-mobility group protein-1 (HMG-1) (1:1000, Cell Signaling), IL-10 (1:1000, Abcam), IL-34 (1:400, Abcam), matrix metalloproteinase (MMP)-9 (1:2000, Abcam), macrophage inflammatory protein (MIP)-1 $\alpha$ (1:1000, Abcam), and actin (1:10000, Millipore)], for 1 hour at room temperature. Horseradish peroxidase-conjugated anti-rabbit immunoglobulin IgG (1:2000, Cell Signaling) was used as a secondary antibody for one-hour incubation at room temperature. The washing procedure was repeated eight times within one hour. Immunoreactive bands were visualized by enhanced chemiluminescence (ECL; Amersham Biosciences) and exposed to Biomax L film (Kodak). For the purpose of quantification, ECL signals were digitized using Labwork software (UVP).

\section{Author contributions}

HKY, MSL, and FYL conceived and designed the study, acquired and analyzed data, and drafted the manuscript. CKS, HTC, PHS, KCL, and SFK were responsible for the laboratory assays and troubleshooting. KHC, CMY, CFL, and PLS acquired, analyzed, and interpreted data. All authors read and approved the final manuscript.

\section{CONFLICTS OF INTEREST}

The authors declare that they have no conflicts of interest.

\section{REFERENCES}

1. Hamdan A, Shapira Y, Bengal T, Mansur M, Vaturi M, Sulkes J, Battler A, Sagie A. Tissue Doppler imaging in patients with advanced heart failure: relation to functional class and prognosis. J Heart Lung Transplant. 2006; 25:214-218.

2. Rossi D, Pinna GD, La Rovere MT, Traversi E. Prognostic significance of tissue-Doppler imaging in chronic heart failure patients on transplant waiting list: a comparative study with right heart catheterization. Eur J Echocardiogr. 2011; 12:112-119.

3. Fendler TJ, Swetz KM, Allen LA. Team-based palliative and end-of-life care for heart failure. Heart Fail Clin. 2015; 11:479-498.

4. Investigators S, Yusuf S, Pitt B, Davis CE, Hood WB, Cohn $J N$. Effect of enalapril on survival in patients with reduced left ventricular ejection fractions and congestive heart failure. N Engl J Med. 1991; 325:293-302.

5. Pitt B, Zannad F, Remme WJ, Cody R, Castaigne A, Perez A, Palensky J, Wittes J. The effect of spironolactone on morbidity and mortality in patients with severe heart failure. Randomized Aldactone Evaluation Study Investigators. N Engl J Med. 1999; 341:709-717.

6. Poole-Wilson PA, Swedberg K, Cleland JG, Di Lenarda A, Hanrath P, Komajda M, Lubsen J, Lutiger B, Metra M, Remme WJ, Torp-Pedersen C, Scherhag A, Skene A, et al. Comparison of carvedilol and metoprolol on clinical outcomes in patients with chronic heart failure in the Carvedilol Or Metoprolol European Trial (COMET): randomised controlled trial. Lancet. 2003; 362:7-13.

7. Palazzuoli A, Quatrini I, Vecchiato L, Calabria P, Gennari L, Martini G, Nuti R. Left ventricular diastolic function improvement by carvedilol therapy in advanced heart failure. J Cardiovasc Pharmacol. 2005; 45:563-568.

8. Givertz MM, Massie BM, Fields TK, Pearson LL, Dittrich HC; CKI-201 and CKI-202 Investigators. The effects of KW-3902, an adenosine A1-receptor antagonist, on diuresis and renal function in patients with acute decompensated heart failure and renal impairment or diuretic resistance. J Am Coll Cardiol. 2007; 50:1551-1560.

9. Konstam MA, Gheorghiade M, Burnett JC Jr, Grinfeld L, Maggioni AP, Swedberg K, Udelson JE, Zannad F, Cook T, Ouyang J, Zimmer C, Orlandi C, Efficacy of vasopressin antagonism in heart failure outcome study with tolvaptan I. Effects of oral tolvaptan in patients hospitalized for worsening heart failure: the EVEREST Outcome Trial. JAMA. 2007; 297:1319-1331. 
10. Fox K, Ford I, Steg PG, Tendera M, Robertson M, Ferrari $\mathrm{R}$, investigators $\mathrm{B}$. Heart rate as a prognostic risk factor in patients with coronary artery disease and left-ventricular systolic dysfunction (BEAUTIFUL): a subgroup analysis of a randomised controlled trial. Lancet. 2008; 372:817-821.

11. O'Connor CM, Starling RC, Hernandez AF, Armstrong PW, Dickstein K, Hasselblad V, Heizer GM, Komajda M, Massie BM, McMurray JJ, Nieminen MS, Reist CJ, Rouleau JL, et al. Effect of nesiritide in patients with acute decompensated heart failure. N Engl J Med. 2011; 365:32-43.

12. Hanna MA, Tang WH, Teo BW, O’Neill JO, Weinstein DM, Lau SM, Van Lente F, Starling RC, Paganini EP, Taylor DO. Extracorporeal ultrafiltration vs. conventional diuretic therapy in advanced decompensated heart failure. Congest Heart Fail. 2012; 18:54-63.

13. Ogliari G, Mahinrad S, Stott DJ, Jukema JW, Mooijaart SP, Macfarlane PW, Clark EN, Kearney PM, Westendorp RG, de Craen AJ, Sabayan B. Resting heart rate, heart rate variability and functional decline in old age. CMAJ. 2015; 187:E442-449.

14. Bristow MR, Saxon LA, Boehmer J, Krueger S, Kass DA, De Marco T, Carson P, DiCarlo L, DeMets D, White BG, DeVries DW, Feldman AM; Comparison of Medical Therapy $\mathrm{P}$, et al. Cardiac-resynchronization therapy with or without an implantable defibrillator in advanced chronic heart failure. N Engl J Med. 2004; 350:2140-2150.

15. Moss AJ, Hall WJ, Cannom DS, Klein H, Brown MW, Daubert JP, Estes NA 3rd, Foster E, Greenberg H, Higgins SL, Pfeffer MA, Solomon SD, Wilber D, et al. Cardiacresynchronization therapy for the prevention of heart-failure events. N Engl J Med. 2009; 361:1329-1338.

16. Zareba W, Zareba KM. Which patients with chronic heart failure should be referred for CRT-D implantation? Practical implications of current clinical research. Pol Arch Med Wewn. 2010; 120:95-102.

17. St John Sutton M, Cerkvenik J, Borlaug BA, Daubert C, Gold MR, Ghio S, Chirinos JA, Linde C, Ky B. Effects of cardiac resynchronization therapy on cardiac remodeling and contractile function: results from resynchronization reverses remodeling in systolic left ventricular dysfunction (REVERSE). J Am Heart Assoc. 2015; 4:e002054.

18. Mehra MR, Uber PA, Uber WE, Scott RL, Park MH. Allosensitization in heart transplantation: implications and management strategies. Curr Opin Cardiol. 2003; 18:153-158.

19. Kirklin JK, Pambukian SV, McGiffin DC, Benza RL. Current outcomes following heart transplantation. Semin Thorac Cardiovasc Surg. 2004; 16:395-403.

20. Lindenfeld J, Miller GG, Shakar SF, Zolty R, Lowes BD, Wolfel EE, Mestroni L, Page RL 2nd, Kobashigawa J. Drug therapy in the heart transplant recipient: part I: cardiac rejection and immunosuppressive drugs. Circulation. 2004; 110:3734-3740

21. Taylor DO, Edwards LB, Boucek MM, Trulock EP, Aurora P, Christie J, Dobbels F, Rahmel AO, Keck BM, Hertz MI.
Registry of the International Society for Heart and Lung Transplantation: twenty-fourth official adult heart transplant report--2007. J Heart Lung Transplant. 2007; 26:769-781.

22. Yip HK, Sun CK, Chang LT, Chen MC, Liou CW. Time course and prognostic value of plasma levels of $\mathrm{N}$-terminal pro-brain natriuretic peptide in patients after ischemic stroke. Circ J. 2006; 70:447-452.

23. Yuen CM, Chiu CA, Chang LT, Liou CW, Lu CH, Youssef AA, Yip HK. Level and value of interleukin-18 after acute ischemic stroke. Circ J. 2007; 71:1691-1696.

24. Borbely XI, Krishnamoorthy V, Modi S, RowhaniRahbar A, Gibbons E, Souter MJ, Vavilala MS. Temporal changes in left entricular systolic function and use of echocardiography in adult heart donors. Neurocrit Care. 2015; 23:66-71.

25. Li S, Korkmaz S, Loganathan S, Radovits T, Hegedus P, Karck M, Szabo G. Short- and long-term effects of brain death on post-transplant graft function in a rodent model. Interact Cardiovasc Thorac Surg. 2015; 20:379-386.

26. Krishnamoorthy V, Borbely X, Rowhani-Rahbar A, Souter MJ, Gibbons E, Vavilala MS. Cardiac dysfunction following brain death in children: prevalence, normalization, and transplantation. Pediatr Crit Care Med. 2015; 16:e107-112.

27. Hegedus P, Li S, Korkmaz-Icoz S, Radovits T, Mayer T, Al Said S, Brlecic P, Karck M, Merkely B, Szabo G. Dimethyloxalylglycine treatment of brain-dead donor rats improves both donor and graft left ventricular function after heart transplantation. J Heart Lung Transplant. 2016; 35:99-107.

28. Bulcao CF, D'Souza KM, Malhotra R, Staron M, Duffy JY, Pandalai PK, Jeevanandam V, Akhter SA. Activation of JAK-STAT and nitric oxide signaling as a mechanism for donor heart dysfunction. J Heart Lung Transplant. 2010; 29:346-351.

29. Chang LT, Yuen CM, Liou CW, Lu CH, Chang WN, Youssef AA, Yip HK. Link between interleukin-10 level and outcome after ischemic stroke. Neuroimmunomodulation. 2010; 17:223-228.

30. Yeh KH, Tsai TH, Chai HT, Leu S, Chung SY, Chua S, Chen YL, Lin HS, Yuen CM, Yip HK. Comparison of acute versus convalescent stage high-sensitivity C-Reactive protein level in predicting clinical outcome after acute ischemic stroke and impact of erythropoietin. J Transl Med. 2012; 10:6.

31. Tsai TH, Chen YL, Lin HS, Liu CF, Chang HW, Lu CH, Chang WN, Chen SF, Wu CJ, Leu S, Ko SF, Yip HK. Link between lipoprotein-associated phospholipase A2 gene expression of peripheral-blood mononuclear cells and prognostic outcome after acute ischemic stroke. J Atheroscler Thromb. 2012; 19:523-531.

32. Lin HS, Tsai TH, Liu CF, Lu CH, Chang WN, Chen SF, Huang CW, Huang CR, Tsai NW, Huang CC, Liou CW, Lin TK, Lan MY, et al. Serum level and prognostic value of neopterin in patients after ischemic stroke. Clin Biochem. 2012; 45:1596-1601. 
33. Cheng CI, Lin YC, Tsai TH, Lin HS, Liou CW, Chang WN, Lu CH, Yuen CM, Yip HK. The prognostic values of leukocyte Rho kinase activity in acute ischemic stroke. Biomed Res Int. 2014; 2014:214587.

34. Damman J, Hoeger S, Boneschansker L, Theruvath A, Waldherr R, Leuvenink HG, Ploeg RJ, Yard BA, Seelen MA. Targeting complement activation in brain-dead donors improves renal function after transplantation. Transpl Immunol. 2011; 24:233-237.

35. Floerchinger B, Ge X, Lee YL, Jurisch A, Padera RF, Schmid C, Tullius SG. Graft-specific immune cells communicate inflammatory immune responses after brain death. J Heart Lung Transplant. 2012; 31:1293-1300.

36. Floerchinger B, Yuan X, Jurisch A, Timsit MO, Ge X, Lee YL, Schmid C, Tullius SG. Inflammatory immune responses in a reproducible mouse brain death model. Transpl Immunol. 2012; 27:25-29.

37. Barklin A. Systemic inflammation in the brain-dead organ donor. Acta Anaesthesiol Scand. 2009; 53:425-435.

38. Watts RP, Thom O, Fraser JF. Inflammatory signalling associated with brain dead organ donation: from brain injury to brain stem death and posttransplant ischaemia reperfusion injury. J Transplant. 2013; 2013:521369.

39. Wilhelm MJ, Pratschke J, Beato F, Taal M, Kusaka M, Hancock WW, Tilney NL. Activation of the heart by donor brain death accelerates acute rejection after transplantation. Circulation. 2000; 102:2426-2433.

40. Thum T, Bauersachs J, Poole-Wilson PA, Volk HD, Anker $\mathrm{SD}$. The dying stem cell hypothesis: immune modulation as a novel mechanism for progenitor cell therapy in cardiac muscle. J Am Coll Cardiol. 2005; 46:1799-1802.

41. Maumus M, Guerit D, Toupet K, Jorgensen C, Noel D. Mesenchymal stem cell-based therapies in regenerative medicine: applications in rheumatology. Stem Cell Res Ther. $2011 ; 2: 14$.

42. Chen YT, Sun CK, Lin YC, Chang LT, Chen YL, Tsai TH, Chung SY, Chua S, Kao YH, Yen CH, Shao PL, Chang $\mathrm{KC}$, Leu S, et al. Adipose-derived mesenchymal stem cell protects kidneys against ischemia-reperfusion injury through suppressing oxidative stress and inflammatory reaction. J Transl Med. 2011; 9:51.

43. Sun $\mathrm{CK}$, Yen $\mathrm{CH}$, Lin YC, Tsai TH, Chang LT, Kao YH, Chua S, Fu M, Ko SF, Leu S, Yip HK. Autologous transplantation of adipose-derived mesenchymal stem cells markedly reduced acute ischemia-reperfusion lung injury in a rodent model. J Transl Med. 2011; 9:118.

44. Yip HK, Chang YC, Wallace CG, Chang LT, Tsai TH, Chen YL, Chang HW, Leu S, Zhen YY, Tsai CY, Yeh $\mathrm{KH}$, Sun $\mathrm{CK}$, Yen $\mathrm{CH}$. Melatonin treatment improves adipose-derived mesenchymal stem cell therapy for acute lung ischemia-reperfusion injury. J Pineal Res. 2013; 54:207-221.
45. Wang D, Li J, Zhang Y, Zhang M, Chen J, Li X, Hu X, Jiang S, Shi S, Sun L. Umbilical cord mesenchymal stem cell transplantation in active and refractory systemic lupus erythematosus: a multicenter clinical study. Arthritis Res Ther. 2014; 16:R79.

46. Insausti $\mathrm{CL}$, Blanquer $\mathrm{M}$, Garcia-Hernandez AM, Castellanos G, Moraleda JM. Amniotic membrane-derived stem cells: immunomodulatory properties and potential clinical application. Stem Cells Cloning. 2014; 7:53-63.

47. Kox M, Pickkers P. Reply: mesenchymal stromal (stem) cell therapy: an emerging immunomodulatory strategy for the adjunctive treatment of sepsis. Am J Respir Crit Care Med. 2014; 189:364-365.

48. Ben-Ami E, Miller A, Berrih-Aknin S. T cells from autoimmune patients display reduced sensitivity to immunoregulation by mesenchymal stem cells: role of IL-2. Autoimmun Rev. 2014; 13:187-196.

49. Chang CL, Sung PH, Sun CK, Chen CH, Chiang HJ, Huang TH, Chen YL, Zhen YY, Chai HT, Chung SY, Tong MS, Chang HW, Chen HH, et al. Protective effect of melatoninsupported adipose-derived mesenchymal stem cells against small bowel ischemia-reperfusion injury in rat. J Pineal Res. 2015; 59:206-220.

50. Casiraghi F, Azzollini N, Cassis P, Imberti B, Morigi M, Cugini D, Cavinato RA, Todeschini M, Solini S, Sonzogni A, Perico N, Remuzzi G, Noris M. Pretransplant infusion of mesenchymal stem cells prolongs the survival of a semiallogeneic heart transplant through the generation of regulatory T cells. J Immunol. 2008; 181:3933-3946.

51. Popp FC, Eggenhofer E, Renner P, Slowik P, Lang SA, Kaspar H, Geissler EK, Piso P, Schlitt HJ, Dahlke MH. Mesenchymal stem cells can induce long-term acceptance of solid organ allografts in synergy with low-dose mycophenolate. Transpl Immunol. 2008; 20:55-60.

52. Smith JW, Ghazi CA, Cain BC, Hurt RT, Garrison RN, Matheson PJ. Direct peritoneal resuscitation improves inflammation, liver blood flow, and pulmonary edema in a rat model of acute brain death. J Am Coll Surg. 2014; 219:79-87.

53. Yen DH, Yien HW, Wang LM, Lee CH, Chan SH. Spectral analysis of systemic arterial pressure and heart rate signals of patients with acute respiratory failure induced by severe organophosphate poisoning. Crit Care Med. 2000; 28:2805-2811.

54. Chan JY, Chang AY, Chan SH. New insights on brain stem death: from bedside to bench. Prog Neurobiol. 2005; 77:396-425.

55. Chan JY, Ou CC, Wang LL, Chan SH. Heat shock protein 70 confers cardiovascular protection during endotoxemia via inhibition of nuclear factor-kappaB activation and inducible nitric oxide synthase expression in the rostral ventrolateral medulla. Circulation. 2004; 110:3560-3566. 